\title{
INEQUALITY AND DISABILITY: IN STATISTICAL TERMS, WHAT ELSE DO WE NEED TO KNOW?
}

\author{
Paulo Tadeu Meira e Silva de OLIVEIRA ${ }^{1}$
}

- ABSTRACT: Social inequality is the phenomenon that differentiates between people in the context of the same society, placing some individuals in structurally more advantageous conditions than others. It manifests itself in all aspects: political, economic among others. The main causes of inequality are investment lack in social areas, health and education. Among the consequences of inequality, we highlight: increased violence, poverty, delay in economic progress; hunger, destruction and infant mortality; young marginalization people, and finally; rising unemployment. Among the main inequality types, we highlight: people with and without disabilities, regions, races; income and sex. To measure this inequality, we highlight HDI, Theil and MPI. A person with a disability is any person who presents a loss or abnormality that generates an inability to perform one or more activities, and these characteristics hinder their social inclusion, access to the labor market, transportation, education, financing and training; urban and environmental barriers, and finally; ignorance of employers. Situations like these provide disabilities people with lower wages when employed, worse purchasing power, less social participation providing greater exclusion and disadvantaged situations when compared to those without disabilities. For this work we used exploratory analysis techniques considering data sets from the 2010 IBGE Census and UNDP.

- KEYWORDS: Exploratory analysis; 2010 population census; social inequality index; disabilities people; studies by municipality; profile analysis;

\section{Introduction}

Social inequality is the economic difference that exists between certain groups of people within the same society. This inequality tends to affect mainly people with greater vulnerability, as is the case of disabled people, who in most cases are taken to a vulnerability situation. As a way of measuring this inequality, there are indices such as Gini, HDI, Theil, poverty index, among others.

It is currently considered a fact that disabled people have existed throughout history (SILVA, 1986; CARVALHO, 2001). Gradually, societies began to realize that, in addition to charity and assistance, such people should be included in programs and public policies that could enhance their productive potential (SILVA, 1986; DOMINGO, 2006; FIGUEIRA, 2008). In reality, disabled people themselves showed that they could and wanted to study, work, have their voices heard and be fully included in society (GARCIA, 2010).

\footnotetext{
${ }^{1}$ Universidade de São Paulo - USP, Escola de Engenharia de São Carlos, Departamento de Engenharia de Transportes, CEP: 13566590, São Carlos, SP, Brasil E-mail: poliver@usp.br 
When analyzing the social, economic, cultural, psychological and behavioral factors that influence the occurrence of health problems and their risk factors in the population, we recognize the distribution and determinants of illnesses, as well as damage to health and associated events. This understanding is fundamental for the improvement of public policies, as it allows proposing specific measures for the prevention, control, or eradication of health problems in this population, which subsidizes the planning of public health policies to better meet their needs.

Disabled people, in addition to the social conditions of the health-disease process, also face attitudinal, architectural and financial barriers, inherent to the very condition that lead them to inequality situations.

For this work, it intends to explore and show a little bit about these relationships statistically in order to show the inequality degree between disabled people and without disabilities considering the indices mentioned above and that of poverty considering people interviewed who answered the complete IBGE questionnaire and the data obtained in the Human Development Atlas by municipality.

\section{Materials and methods}

\subsection{Disabled people}

Disabled Person is any person who presents a loss or abnormality of a structure or function that generates disability for the performance of activities that hinder their social inclusion (DIAS, 2011). Disabilities can be permanent or temporary and limit the ability to perform one or more activities such as seeing, listening, walking and intellectual. It is characterized as a complex multidimensional experience and imposes several measurement challenges (OLIVEIRA, 2017).

In different times and cultures, the treatment of disabled people has varied. However, there has always been a historical constant: marginalization. Terms like idiots, and exceptional are some of the nominations used to try to define the disabled throughout human history. In contemporary times, unusual people are still designated by many of these terms and rejected by society, legitimizing prejudice (SILVA, 1986).

Gradually, societies began to realize that, in addition to charity and assistance, such people should be included in programs and public policies that could enhance their productive potential (SILVA, 1986; DOMINGO, 2006; FIGUEIRA, 2008). In reality, disabled people themselves showed that they could and wanted to study, work, have their voices heard and be fully included in society (GARCIA, 2010).

Worldwide, disabled people have worse health prospects, worst education levels, lower economic participation and higher poverty rates compared to people without disabilities. This is partly due to the fact that disabled people face barriers to access services that many of us have long considered guaranteed, such as health, education, employment, transport and information. Such difficulties are exacerbated in the poorest communities (HAWKING, 2011).

We also know that disabled people are characterized by:

i) According to the WHO (World Health Organization), it is estimated that more than one billion people ( $15 \%$ of the world population in 2010), live with some form of disability. 
ii) The number of disabilities persons grows due to factors such as population aging, low income, worse health and financial conditions, and environmental factors such as traffic accidents, natural challenges, conflicts, diet and drug abuse, and finally;

iii) Experience of disability resulting from the interaction between health conditions, personal and environmental factors that vary widely. While disability is related to disadvantage, not all disabled people experience these disadvantages equally. Disability proportionally affects vulnerable populations with a higher prevalence in low-income countries, poorer people, women, the elderly and those from minority ethnic groups.

According to a census conducted in 2010 by the Geography and Statistics Brazilian Institute (IBGE), there are 45.6 million people in Brazil with at least one disability, which represents $23.9 \%$ of the Brazilian population. Of this number, we have $77.9 \%$ (35.5 million) with visual disabled; $21.9 \%$ (10 million) hearing; $29.7 \%$ (13.5 million) walking, and finally; $6.4 \%$ (3.4 million) with permanent intellectual disability; from the point of view of the number of disabilities we obtain $72 \%$ with a disability and $28 \%$ with more than one disability; $22.2 \%$ have no education (32.8 million); $27.5 \%$ (12.5 million) live in extreme poverty; $92.3 \%$ (43.1 million) are of working age; of these, $43.7 \%$ (20 million) perform activities characterized as work, $88 \%$ (17.6 million) perform paid activities, and; $36.1 \%$ (7.2 million people) do not have a formal contract.

Disability is characterized as a complex multidimensional experience, imposing numerous measurement challenges. The approaches to measuring disability vary between different countries and influence the results. Operational measures of disability vary according to the purpose and application of the data, the design of the disability, the aspects of the disability being examined: disabilities, limitations on carrying out certain activities, related health problems, environmental factors, the types of issues information sources, data collection methods and operating expectations.

According to the WHO, in statistical terms, we should improve national statistics on disability, improve data comparability at national and international level, and finally; develop appropriate tools and fill gaps between different surveys.

Life Quality is understood as the individual's perception of his position in life in the context of the culture and value system in which he lives, and in relation to his goals, expectations, standards and concerns. It is a comprehensive concept that incorporates in a complex way physical health, psychological status, independence life, social relationships, personal beliefs and environmental factors relationships that affect them (HAWKING, 2011).

The life quality has issue been growing in importance in several aspects in recent years, mainly with regard to its assessment or measurement, be it individual or relatively (FERRO, 2012).

The term disability means a physical, intellectual or sensory disability, whether permanent or temporary, which limits the ability to exercise one or more activities.

According to the 2010 IBGE Census, the disabilities were divided into physical, listening, visual and intellectual.

In its questionnaire, IBGE established four different degrees of severity for each of the first three types of disabilities cited below: 1 - it cannot in any way; 2 - can, but with great difficulty; 3 - can, but with some difficulty; and finally; 4 - does not present any difficulties, and for intellectual the following possibilities were considered: 1 - yes, if you have an intellectual disability, which is permanent and 2 - no, if you do not. 
The most serious cases are considered as candidates to obtain assistance and receive benefits from public authorities, that is, those represented by groups 1 and 2 and all cases considered to be of intellectual disability. In this work, however, we are considering all possible cases.

\subsection{Social inequality}

Social inequality is the phenomenon in which differentiation occurs between people in the context of the same society, placing some individuals in structurally more advantageous conditions than others. It manifests itself in all aspects: cultural, daily, political, geographic space, among others, but it is the most well-known face on the economic plane, in which a large part of the population does not have enough income to enjoy minimum living conditions.

This inequality refers to relational processes in society that have the effect of limiting or damaging the status of a particular group, class or social circle. Areas of social inequality include access to voting rights, expression freedom and assembly, the extension of property rights and access to education, health, housing conditions, work, travel, transportation, holidays and other assets and services (CONCEIÇÃO, 2019).

This form of inequality limits the social status of these people, in addition to their access to these rights, proving to be a factor of setback in economic growth.

It is a vicious cycle: these groups remain with their privileges and in a restricted circle, relating socially and economically for generations on end, perpetuating inequality. For example, inequality increases the probability of people becoming disabled people, which in turn increases that inequality.

Among the possible causes of social inequality, the following stand out: poor income distribution and economic power concentration; land division unevenly; investment lack in social areas, in culture, in assistance to the most needy populations, in health, inequality in the education quality according to social classes, school dropout and the difficulty of the lower classes in achieving good schooling and professional qualification, and finally; lack of job opportunities.

As possible consequences of social inequality, it is possible to highlight: increased poverty, violence, crime, delay in economic progress and poor quality of food; poor housing conditions, slums and lack of basic sanitation; precarious health and high infant mortality rate; social marginalization and violence; unemployment; and finally; poor quality of public services offered.

According to the study released by the IBGE, the concentration of income increased in 2018 in Brazil. The data show that the monthly income of the richest $1 \%$ of the country is almost 34 times higher than the income of the poorest half of the population.

For its measurement it is possible to highlight:

\subsubsection{Human Development Index}

The Human Development Index (HDI) is a measure used to classify countries by their degree of "human development" and to help classify countries as developed, developing and underdeveloped. The statistics are composed from data on life expectancy at birth, education and GDP per capita collected at the national level. Each year, UN member countries are classified according to these measures. The HDI is also used by local 
organizations or companies to measure the development of subnational entities such as states, cities, regions, etc.

The system is highly criticized, as it is not indicative of real human progress; according to the index, for example, a country like Saudi Arabia has one of the best ratings.

The Municipal Human Development Index (MHDI) is a measure composed of indicators of three dimensions of human development: longevity, education and income. The index ranges from 0 to 1 equivalent to the global index. The closer to 1 , the greater the human development.

As an evaluation criterion, the HDI combines three dimensions: a long and healthy life: Life expectancy at birth (represented by L); Access to knowledge: Average Years of Study and Expected Years of Schooling (indicated by K), and finally; A decent standard of living: GDP (PPP) per capita (Income, called I)

The calculation method for the HDI consists of calculating the following expression: $H D I=\sqrt[3]{L . K . I}$, where $\mathrm{L}$ is the longevity index at birth; $\mathrm{k}$ it is access to knowledge; and finally. I is the income index as shown in Figure 1.

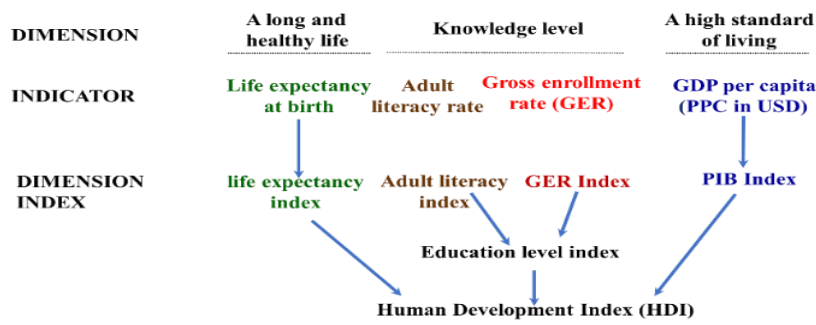

Figure 1 - Routines for calculating the human development index

Figure 1 shows schematically and succinctly which dimensions and routines are used to calculate the HDI.

\subsubsection{Gini coefficient}

The Gini coefficient consists of a number between 0 and 1 , where 0 corresponds to complete equality and 1 corresponds to complete inequality (where one person receives all income and the others receive nothing), as can be seen in Figure 2.

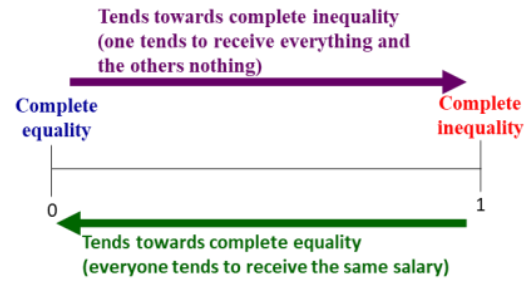

Figure 2 - Gini coefficient.

The Gini coefficient is obtained by the expression (1): 


$$
G=1-\sum_{k=0}^{k=n-1}\left(X_{k+1}-X_{k}\right)\left({ }^{`} Y_{k+1}+Y_{k}\right)
$$

where $\mathrm{G}$ is the Gini coefficient; $\mathrm{X}$ is the cumulative proportion of the population variable, and, finally; $\mathrm{Y}$ is the cumulative proportion of the income variable.

The Gini coefficient is widely used in several fields of study, such as sociology, economics, health sciences, ecology, engineering and agriculture. For example, in social sciences and economics, in addition to the income-related Gini coefficient, researchers have published coefficients related to education and opportunities.

In addition, the study showed that the income of the poorest $5 \%$ fell by $3 \%$, while the income of the richest $1 \%$ increased by $8 \%$. Thus, the Gini Index, an instrument used to measure inequality in Brazil, rose again. In 2018, it reached the number of 0.509. It is worth remembering that the index ranges from zero to one. The closer to one, the worse the income distribution in the country.

\subsubsection{Theil index}

Theil's index is a statistical measure of income distribution. Theil's index is given by the Neperian logarithm of the ratio between the arithmetic and geometric means of the average per capita family income. If the ratio between the averages is equal to 1, Theil will be equal to zero, indicating perfect distribution. The higher the ratio between the averages, the greater the value for Theil's index, and the worse the income distribution, as show in Figure 3 below:

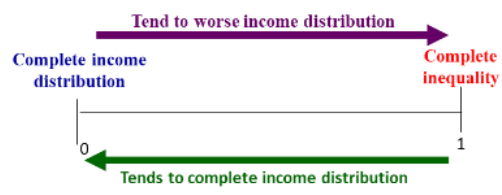

Figure 3 - Theil coefficient.

Theil's index is given by the following formula: Theil $=1-\exp (-\mathrm{R})$. This value is between 0 and 1 and the higher this value, the worse the distribution. Among its qualities are that it is symmetrical, independent of population replications, independent of the average and satisfies the Pigou-Dalton Principle (inequality grows as a result of regressive transfers). Even countries like the United States are being described as highly unequal.

\subsubsection{Multidimensional Poverty Index}

The Multidimensional Poverty Index (MPI) consists of a versatile methodology to incorporate multiple criteria, indicators, weights and cuts that allow appropriations to meet the demands according to the reality of the territory to be studied.

MPI was launched in 2010 by the United Nations Development Program (UNDP) as a complementary alternative to monetary measures to measure poverty.

Poverty is a social question characterized by several factors, such as social exclusion, low schooling, poor housing conditions and access lack to goods and services. Thus, income 
alone is not necessarily a sufficient indicator to indicate an improvement in people's life quality.

The MPI analyses poverty in its various dimensions, enabling the management of information, providing subsidies for focusing public policies and prioritizing actions to overcome them, as well as for the definition of priority families and territories.

The value of a territory's MPI is the product of the incidence and intensity of poverty. The MPI varies between 0 (poverty absence) and 1 (poverty extreme). Poverty can be estimated by size of the MPI and for all dimensions. In each dimension, the score ranges from 0 to 0.25 in MPI-A and from 0 to 0.33 in MPI-S.

The closer to 0.25 or 0.33 , the more deprivation there is within each dimension. Multidimensionally poor families are those that score 0.25 or more in MPI-A and 0.33 or more in MPI-S.

This deprivation analysis contributes to the effectiveness of the social program as it helps to prioritize actions and policies to combat the most urgent deprivations.

By comparing the scores at the beginning and at the end of the program, it is possible to identify whether there have been improvements in deprivations and to monitor whether beneficiary families, as well as the territories and municipalities contemplated, are emerging from extreme poverty, as show in Figure 4.

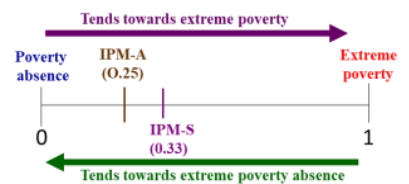

Figure 4 - Multidimensional poverty index

For the health dimension $(\mathrm{H})$, two indicators refer to $\left(\mathrm{H}_{1}\right)$ infant mortality rate and $\left(\mathrm{H}_{2}\right)$ nutrition. For the education dimension, also two indicators $\left(\mathrm{E}_{1}\right)$ schooling years and $\left(E_{2}\right)$ number of children enrolled. Finally, for the life standard dimension (LS), six indicators contribute: $\left(\mathrm{LS}_{1}\right)$ electricity access; $\left(\mathrm{LS}_{2}\right)$ access to clean drinking water; $\left(\mathrm{LS}_{3}\right)$ access to appropriate sanitation; $\left(\mathrm{LS}_{4}\right)$ access to cooking fuel; $\left(\mathrm{LS}_{5}\right)$ access to a dirt floor house; $\left(\mathrm{LS}_{6}\right)$ and, not having a car, the property, at most, of two of the following goods: bicycle, motorcycle, radio, refrigerator, telephone and television, as shown in Figure 5.

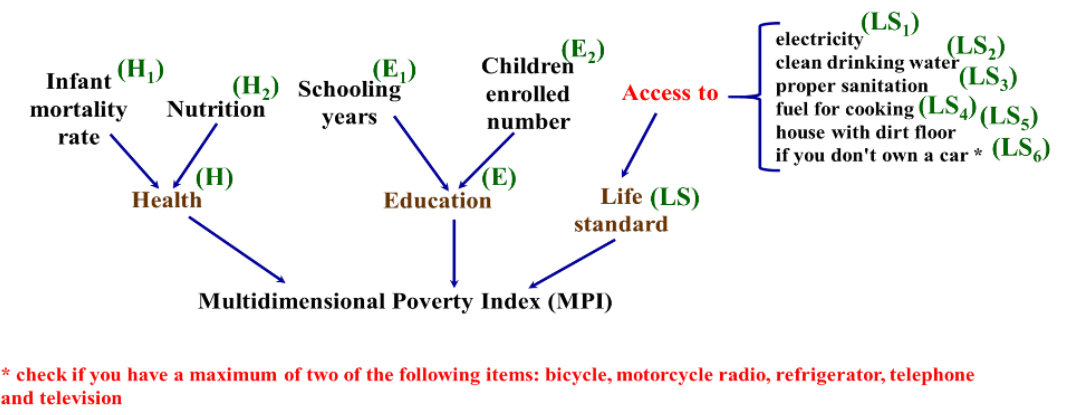

Figure 5 - Multidimensional Poverty Index 
Methodologically, the MPI results from the product between the multidimensional rate of counting people and the intensity / poverty breadth.

Thus, to determine the multidimensional rate of counting people, the ratio between the number of people considered to be multidimensionally poor and the total number of individuals is applied according to the expression (2) below:

$$
I D I M=\frac{\left(x_{\text {obs. }}-x_{\min .}\right)}{\left(x_{\min .}-x_{\max }\right)},
$$

where DIMI is the dimension index; $x_{\text {obs. }}$ is the observed value, $x_{\max }$. is the maximum value, and finally; $\mathrm{x}_{\min }$. is the minimum value.

The next step is to calculate the intensity of poverty that can be calculated according to the expression (3) below:

$$
\mathrm{A}=\frac{\sum_{l}^{q} c}{q \times d}
$$

where $\mathrm{A}$ is the intensity of poverty; $\mathrm{q}$ the multidimensionally poor people group $\mathrm{c}$ the set of families with weighted deprivation scores, and finally, $\mathrm{n}$ is the total population.

Finally, calculate the MPI according to expression (4):

$$
M P I=A \times H
$$

where MPI is the multidimensional poverty index; $\mathrm{A}$ is the intensity of poverty, and finally; $\mathrm{H}$ is the proportion of people who are multidimensionally poor.

\subsection{Compositional data}

In statistics, compositional data are quantitative descriptions of parts of a whole, which communicate information exclusively in relation to the whole. The most striking feature of this type of data is that its sum is always equal to a constant ( 1 for proportions and 100 for percentages). Such data is very common in research areas such as geology and soil science. Examples of compositional data are the size distribution of mineral particles (sand, saltpetre and clay) in a soil or the concentration of cations in the soil solution. For this article, data from the 2010 IBGE Demographic Census are being considered for proportions of different variables such as disabled people, education level, main job type, among others.

The first recommendations related to the statistical analysis of compositional data, refer to an article by Karl Pearson from 1897 on spurious correlations. The article points out problems arising from the use of traditional statistical methods, as parts of a whole. But his warnings were ignored until around 1960, when geologist Felix Chayes (1960) also warned against the application of standard multivariate analysis for compositional data, in order to avoid inconsistencies due to the unit sum restriction that were systematized by Aitchison (2011).

A $\mathbf{n} \times \mathbf{p}$ dimension data matrix is compositional if the sum of its lines is constant, and sub compositional if the variables form subsets of a compositional data matrix. Let us 
consider a $\mathbf{n} \times \mathbf{p}$ matrix of fully compositional data if it adds lines to a constant, and sub compositional if the variables are a subset of a fully defined composition data set. These data occur widely in archaeometry, where it is common to determine the chemical composition of glass, ceramics, metal or other artifacts using techniques such as neutron activation analysis. The interest often revolves around whether there are different chemical groups within the data and whether, for example, they can be associated with different origins or manufacturing technologies (BAXTER, 1999). The sample space of the compositional data is; therefore, simple space is a $\mathbf{D}-\mathbf{1}$ dimensional subset $\boldsymbol{R}^{\boldsymbol{D}}$. Standard statistical methods can lead to misleading results if they are applied directly to the original closed data. For this reason, centred log ratio (CLR) was introduced. The CLR transformation is a transformation from $S^{D}$ to $R^{D}$, and the result of an observation $x \in R^{D}$ is the transformed data $\boldsymbol{y} \in \boldsymbol{R}^{\boldsymbol{D}}$ with

$$
y=\left(y_{1}, \cdots, y_{D}\right)^{\prime}=\left(\log \frac{x_{1}}{\sqrt[D]{\prod_{i=1}^{D} x_{i}}}, \cdots, \log \frac{x_{D}}{\sqrt[D]{\prod_{i=1}^{D} x_{i}}}\right)
$$

Compositional data has important particular properties that assist in the application of standardized statistical techniques in such concentration data. These statistical techniques are standardized for use in interval data ranging from $-\infty$ to $+\infty$. If one component increases, another must remain constant and another must decrease. This means that the results of standard statistical analysis of the relationship between concentration data components or parts in a compositional data set can be overshadowed by spurious effects (BUCCIANTTI, 2006).

In this study, proportions of variables related to disability were used as a function of variables related to education, family, work, housing conditions, other assets and life quality on the total respondents of these variables (AITCHISON, 2011).

\subsection{Fertility index}

Another topic of interest in exploratory data analysis concerns the fertility rate that can be used in comparative studies of inequality in different groups of the population, as shown in the following study.

According to data from the World Population Status Report 2010, from the United Nations Population Fund (FNUAP), the fertility rate is 2.52 children per woman. This result confirms a worldwide trend of reduction in the number of children.

This fall in the fertility rate is a consequence of several factors, such as sex education projects, family planning, use of contraceptive methods, greater participation of women in the labour market, urbanization expansion among others. For population replacement to be assured, the fertility rate cannot be less than 2.1 children per woman, as the two children replace the parents and the 0.1 fraction is necessary to compensate individuals who die before reaching age reproductive. That is why countries like Denmark have stimulated an increase in the number of children per couple.

The fertility rate is given by the expression (5) below: 


$$
I=\frac{n_{\text {children }}}{n_{\text {women }}}
$$

where $\boldsymbol{I}$ is the fertility index, $\boldsymbol{n}_{\text {children }}$ is the number of children these women had and $n_{\text {women }}$ are the number of women considered fertile according to the definition adopted.

In the case of Brazil, considering women aged 10 and over, a fertility rate of 2.10 children per woman was obtained according to data from the 2010 IBGE Census, which means a balanced population (CAETANO, 2008).

\subsection{Cross-sectional studies}

When information on a variety of variables is collected simultaneously from a group or population of individuals at a specific point in time, and therefore be seen as photographic evaluations of groups or individuals' populations, the term being used to indicate that individuals are being studied at a specific point in time. In this work, the cross-section is the period in which the last IBGE census was carried out (GIOLO, 2017).

In this type of study, it is possible to highlight as advantages the low cost, ease of execution and more objective data collection. On the other hand, it has limitations such as data collection at a single point in time; difficulty in differentiating whether they are new cases or their duration, and finally; it is not possible to affirm that a given factor preceded the occurrence of a certain disease in time and causally or that a person becomes a disabled person (BASTOS and DUQUIA, 2007).

\subsection{Profile analysis}

It is a statistical technique that involves observations from a set of research units (population, for example) classified into different subpopulations according to disabled people, together people with and without disabilities, and people without disabled. In this context, the corresponding observation units can essentially be seen as response profiles associated with them (SINGER and ANDRADE, 1986).

In this work we consider education level, work type and income.

\subsection{Variables considered in the analysis}

Figure 6 shows the variables that were considered in the analysis based on data from the IBGE 2010 Demographic Census for the 20800804 people who answered the complete questionnaire divided into the groups disabled people (8 variables), identification (12 variables), education level (8 variables), family (4 variables), work (12 variables), housing conditions (17 variables) and other assets (11 variables). 


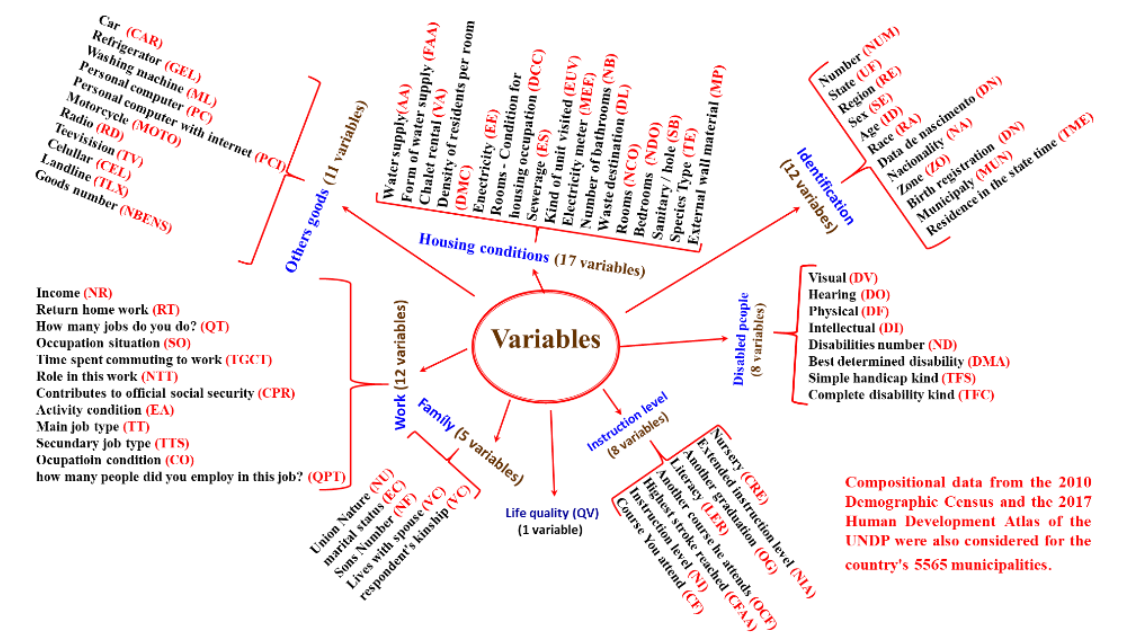

Figure 6 - Set of variables considered by allocated group.

\section{Results and Discussion}

In this study we used data from the IBGE 2010 Demographic Census, PNUD together with and compositional data by municipalities obtained in the aforementioned 2010 census and variables created for a life quality study according to Oliveira (2017) and we used the following programs for analysis: SPSS 25, Minitab 19 and Excel 2019.

For the elaboration of this work we used Data Explory Analysis (DEA) for analysis that we highlight:

Step 1: The graph of distribution of the HDI was obtained (Figure 7). average monthly income in minimum wage was calculated for disabled people (blue line) and without disabled people (red line) for the variables number of assets (Figure 8), race (Figure 9), expanded education level (Figure 10), main job type (Figure11) and distribution by disability type (Figure 12); descriptive measures for some indexes and proportions by municipality (Table 1), and finally; considering people with and without disabilities for distribution by goods number (Table 2), race (Table 3), expanded education level (Table 4), and main job type (Table 5).

Figure 7 shows the HDI values distribution so that values greater than 0.800 (in blue) are more concentrated in the South and Southeast regions; high values in the range between 0.7 and 0.799 (in green) are concentrated in the South, Southeast and Midwest regions; the average values (in yellow) that belong to the 0.6 and 0.6999 range are more located in the central west region, but are very present in all regions of the country; then, very low values (orange) belonging to the range between 0.5 and 0.599 occur more in the North and 
Northeast regions, and, finally; very low values (in red), with values less than 0.5 are more concentrated in the North and Northeast regions.

The graphics in figures 8 to 11 show profiles diagrams and tables with income distribution in minimum wage $\left(\mathrm{mw}^{* 2}\right)$ for disabled people (in blue) and without disabled people (in red) and tables 2 (goods number), 3(race), 4(extended instruction level) and 5 (work main type).

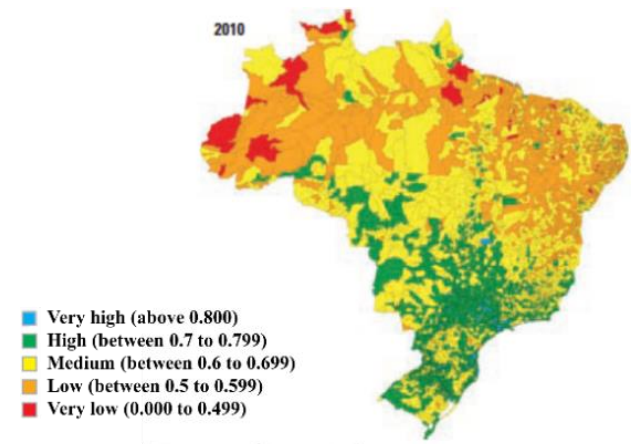

Figure 7 - MHDI values distribution by municipality across Brazil.

Table 1 presents descriptive measures for the GINI and THEIL coefficients; the indexes MHDI, MHDI-E, MHDI-R and MHDI-L, and finally; for some proportions related to visual, hearing, physical, intellectual, multiple and without disabilities.

Table 1 - Descriptive measures

\begin{tabular}{|c|c|c|c|c|c|c|c|c|}
\hline & Minimum & County & UF & Maximum & County & UF & Mean & Variance \\
\hline GINI & 0,280000 & São José do Hortencio & $\mathrm{RS}$ & 0,800000 & SÃO GABRIEL DA CACHOEIRA & $\mathrm{AM}$ & 0,494381 & 0,004366 \\
\hline THEIL & 0,140000 & São José do Hortencio & RS & 1,360000 & Isaias Coelho & $\mathrm{PI}$ & 0,455695 & 0,016995 \\
\hline IDHM & 0,418000 & Melgaço & $\mathrm{PA}$ & 0,862000 & São Caetano do Sul & $\mathrm{SP}$ & 0,659157 & 0,005184 \\
\hline IDHM_E & 0,207000 & Melgaço & $\mathrm{PA}$ & 0,825000 & Águas de São Pedro & $\mathrm{SP}$ & 0,559094 & 0,008710 \\
\hline IDHM_L & 0,672000 & Roteiro & $\mathrm{AL}$ & 0,894000 & Balneário Camboriú & $\mathrm{SC}$ & 0,801564 & 0,001996 \\
\hline IDHM_R & 0,400000 & Marajá do Sena & MA & 0,891000 & São Caetano do Sul & SP & 0,642873 & 0,006506 \\
\hline pDV1 & 0,000000 & Lagoa do Barro do Piaú & PI & 0,011669 & Maratá & $\mathrm{RS}$ & 0,002036 & 0,000002 \\
\hline pDV2 & 0,001684 & Itapuca & $\mathrm{RS}$ & 0,108513 & São Miguel da Baixa Grande & $\mathrm{PI}$ & 0,035248 & 0,000180 \\
\hline pDO1 & 0,000000 & São Valério do Sul & $\mathrm{RS}$ & 0,010267 & SÃO PAULO & SP & 0,001648 & 0,000001 \\
\hline pDO2 & 0,000000 & Itapuca & $\mathrm{RS}$ & 0,038653 & SÃO PAULO & SP & 0,011142 & 0,000019 \\
\hline pDF1 & 0,000000 & São Valério do Sul & RS & 0,017723 & São Domingos & SC & 0,003888 & 0,000004 \\
\hline pDF2 & 0,000842 & Itapuca & $\mathrm{RS}$ & 0,068317 & Coqueiros do Sul & $\mathrm{RS}$ & 0,021566 & 0,000071 \\
\hline pDI1 & 0,000000 & Itapuca & RS & 0,057088 & Brasilândia do Sul & PR & 0,015127 & 0,000029 \\
\hline pND0 & 0,539711 & Araguainha & MT & 0,973906 & Itapuca & $\mathrm{RS}$ & 0,754633 & 0,002264 \\
\hline pND1 & 0,026094 & Itapuca & $\mathrm{RS}$ & 0,332305 & Antônio Almeida & PI & 0,173771 & 0,000981 \\
\hline $\mathrm{pND} 2$ & 0,000000 & Itapuca & $\mathrm{RS}$ & 0,113014 & Santo André & $\mathrm{SP}$ & 0,053754 & 0,000210 \\
\hline pND3 & 0,000000 & Itapuca & $\mathrm{RS}$ & 0,061415 & União da Serra & $\mathrm{RS}$ & 0,016650 & 0,000037 \\
\hline pND4 & 0,000000 & Itapuca & $\mathrm{RS}$ & 0,009962 & Grandes Rios & $\mathrm{PR}$ & 0,001193 & 0,000001 \\
\hline
\end{tabular}

Analyzing the results in Table 1, it is easy to see that Brazil is marked by disparity, inequality and poor income distribution. For example, for an HDI index of 0.418 considered to be very low, the existence of a municipality such as Melgaço (PA) is noted, there is also the existence of a county such as São Caetano do Sul (SP) with an HDI of 0.862 considered

$2 *$ minimum wage income considered in 2010 when the last IBGE Census was taken, was 510 reais. 
very high; for the GINI and THEIL coefficients, it shows a municipality like São José do Hortencio (RS) that most closely matches equality in terms of income with a GINI index of 0.28 and a better income distribution with THEIL in the amount of 0.14 , while that São Gabriel da Cachoeira (AM) is considered the most unequal with GINI of 0.800 and Isaias Coelho (PI) with the worst income distribution with THEIL of 1.36, and, finally; with regard to disabled people we can mention a county such as Itapuca (RS) with a proportion of disabled people of only $2.61 \%$, while a municipality such as Antonio Almeida (PI) which $33.23 \%$ of its population consists of disabled people. This proportion is considered to be higher than the national estimate of $23.9 \%$.

Results like these characterize a great inequality and worse income distribution that perpetuates throughout the country.

The graph in Figure 8 for possession of the quantity of certain goods that were considered in the 2010 census, namely: radio, television, landline, cell phone, washing machine, refrigerator, computer without internet, computer with internet, motorcycle and car totaling 10 assets.

Table 2 - Distributions for disabled and without disabilities people proportion for goods number

\begin{tabular}{|c|c|c|c|c|c|c|c|c|c|c|c|}
\hline & \multicolumn{11}{|c|}{ GOODS NUMBER } \\
\hline & 0 & 1 & 2 & 3 & 4 & 5 & 6 & 7 & 8 & 9 & 10 \\
\hline \multirow{3}{*}{$\begin{array}{l}\text { WITHOUT } \\
\text { DISABILITY }\end{array}$} & 251969 & 368783 & 800344 & 1750124 & 3046154 & 2635819 & 1860851 & 1457940 & 1417365 & 1800227 & 475232 \\
\hline & $1.59 \%$ & $2.32 \%$ & $5.04 \%$ & $11.03 \%$ & $19.20 \%$ & $16.61 \%$ & $11.73 \%$ & $9.19 \%$ & $8.93 \%$ & $11.35 \%$ & $3.00 \%$ \\
\hline & $75.04 \%$ & $74.40 \%$ & $73.04 \%$ & $72.96 \%$ & $73.98 \%$ & $75.24 \%$ & $76.30 \%$ & 78.04\% & $79.95 \%$ & $81.60 \%$ & $83.73 \%$ \\
\hline \multirow{3}{*}{$\begin{array}{c}\text { DISABLED } \\
\text { PEOPLE }\end{array}$} & 83825 & 126873 & 295400 & 648713 & 1071586 & 867347 & 578013 & 410323 & 355529 & 406032 & 92375 \\
\hline & $1.70 \%$ & $2.57 \%$ & $5.96 \%$ & $13.14 \%$ & $21.71 \%$ & $17.57 \%$ & $11.71 \%$ & $8.31 \%$ & $7.20 \%$ & $8.23 \%$ & $1.87 \%$ \\
\hline & $24.96 \%$ & $25.60 \%$ & $26.96 \%$ & $27.04 \%$ & $26.02 \%$ & $24.76 \%$ & $23.70 \%$ & $21.96 \%$ & $20.05 \%$ & $18.40 \%$ & $16.27 \%$ \\
\hline
\end{tabular}

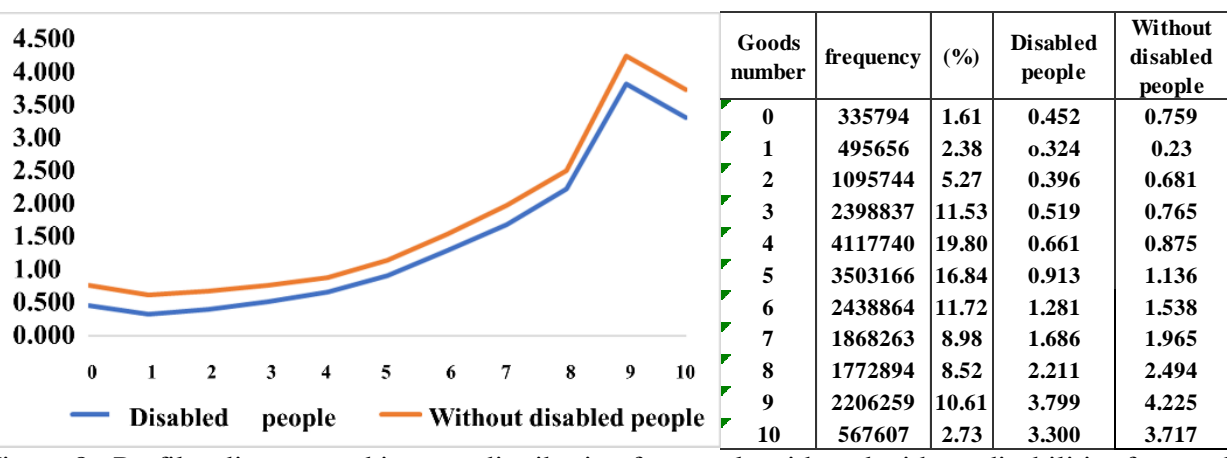

Figure 8 - Profiles diagram and income distribution for people with and without disabilities for goods number.

Notice in Figure 8 that the income increases as the number of goods, except when you add the good 10 since you already had 9 goods, among the people interviewed, the greatest number of them have four goods in a total of 4117740 respondents corresponding to $19.80 \%$ and the smallest amount is represented by the group that does not own any of these assets representing 355794 respondents to $1.61 \%$ of the total respondents, and with the profile diagram it is possible to show that disabled people earn less resulting in a less purchasing 
power, causing them to have less purchasing power, causing greater difficulties in the acquisition of certain goods or products when compared to people without disabilities.

Table 2 shows the distribution of proportions for people with and without disabilities for goods number.

Analysing Table 2 in a comparative way, goods number distribution for people with and without disabilities is possible to verify that disabled people are the majority in proportional terms in possession of a maximum of five of these goods, on the other hand, people without disabilities surpass in the case of have to six or more of these assets.

Also, in Table 2 it can be seen that as assets number in possession increases, the disadvantage of disabled people in relation to those without disabilities increases, reflecting their lower purchasing power because they have more difficulties in obtaining a better education level, leading to worse working conditions and obtaining less income from it.

Next, Figure 9 shows income distribution by race considering disabled people (in blue) and without disabilities (in red), which suggests greater social and economic inequality.

Table 3 - People with and without disabilities proportion distribution by race

\begin{tabular}{l|c|c|c|c|c|}
\hline & \multicolumn{5}{|c|}{ COR OR RACE } \\
\cline { 2 - 6 } & White & Black & Yelow & Brown & Indigenous \\
\hline WITHOUT & $\mathbf{7 4 1 7 2 7 4}$ & $\mathbf{1 0 5 8 2 0 8}$ & $\mathbf{1 5 4 1 4 2}$ & $\mathbf{6 9 7 5 6 3 0}$ & $\mathbf{9 1 5 2 7}$ \\
DISABIIITY & $\mathbf{4 7 . 2 5 \%}$ & $\mathbf{6 . 7 4 \%}$ & $\mathbf{0 . 9 8 \%}$ & $\mathbf{4 4 . 4 4 \%}$ & $\mathbf{0 . 5 8 \%}$ \\
& $\mathbf{7 6 . 4 3 \%}$ & $\mathbf{7 2 . 6 9 \%}$ & $\mathbf{7 2 . 7 3 \%}$ & $\mathbf{7 6 . 2 5 \%}$ & $\mathbf{8 1 . 8 4 \%}$ \\
\hline DISABLED & $\mathbf{2 2 8 7 0 4 0}$ & $\mathbf{3 9 7 6 3 3}$ & $\mathbf{5 7 8 0 3}$ & $\mathbf{2 1 7 3 2 2 4}$ & $\mathbf{2 0 3 0 7}$ \\
PEOPLE & $\mathbf{4 6 . 3 3 \%}$ & $\mathbf{8 . 0 6 \%}$ & $\mathbf{1 . 1 7 \%}$ & $\mathbf{4 4 . 0 3 \%}$ & $\mathbf{0 . 4 1 \%}$ \\
& $\mathbf{2 3 . 5 7 \%}$ & $\mathbf{2 7 . 3 1 \%}$ & $\mathbf{2 7 . 2 7 \%}$ & $\mathbf{2 3 . 7 5 \%}$ & $\mathbf{1 8 . 1 6 \%}$ \\
\hline
\end{tabular}

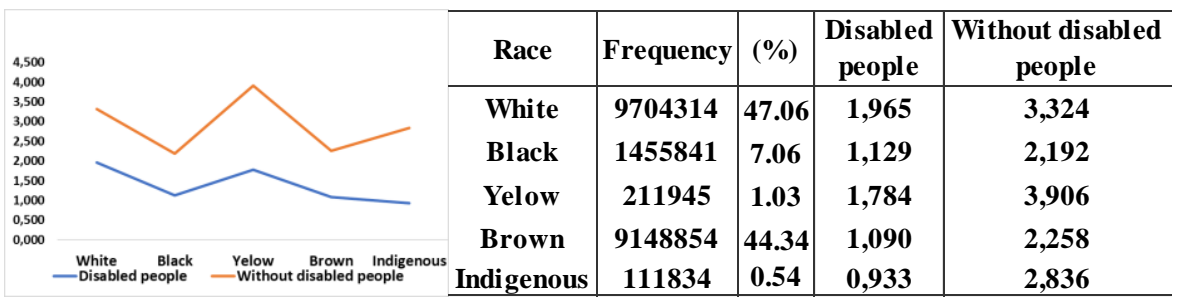

Figure 9 - Profiles diagram and income distribution for people with and without disabilities for race.

Analysing Figure 9, it is observed that for disabled people the highest income is for white people with $1.965 \mathrm{mw}$ followed by yellow people with $1.784 \mathrm{sm}$ and with the worst income was the indigenous race group with $0.933 \mathrm{sm}$, on the other hand, for people without disabilities the highest income is for the yellow race with $3.906 \mathrm{mw}$ followed by the white race with $3.324 \mathrm{mw}$ and the lowest income was for the black race with $2.192 \mathrm{mw}$.

Still in Figure 9 it is also noted that people without disabilities have higher income in all races, however, there are greater disparities for the yellow race than from a $1.784 \mathrm{mw}$ income for disabled people with a second place position to $3.906 \mathrm{mw}$ guaranteeing the first position surpassing races the white and indigenous that for disabled people with an average income of $0.933 \mathrm{mw}$ with the last position considering people without disabilities, the indigenous group moves to an average income of $2.836 \mathrm{mw}$ with a second position. 
These results show that disabled people have greater difficulties in ensuring better purchasing power than people without disabilities.

With regard to indigenous people, it is believed that the fact that most of them live in villages with more precarious infrastructure in terms of transport, health, education, electricity, work and housing, making it even more difficult to provide better assistance to disabled people and also increasing the risk, due to this same precariousness, of anyone becoming disabled.

The situation of the black and brown races continues to bring the remnants of slavery and the discriminatory policy that have weighed on them for centuries with less social and economic and indigenous participation, which in addition to this factor, were and continue to be severely decimated, as it was a civilization that was dominant in Brazil was reduced to just $0.5 \%$ of the population.

It is also noted in Figure 9 that the most numerous races are white, which corresponds to $47.03 \%$ of the population and the least numerous is the indigenous, which represents only $0.54 \%$ of the population and people of the black, brown and indigenous races they are usually contemplated by affirmative action policies and constitute a group that covers $51.95 \%$ of the population.

When analysing Table 3 comparatively the distribution by race between people with and without disabilities, it appears that disabled people have a higher proportion of blacks and yellows, while people without disabilities have a higher proportion of white and indigenous.

Table 3 also shows that for disabled, the proportion of people covered by the quotas represents $52.5 \%$, while for people without disabilities it represents $51.7 \%$.

Table 4 - People with and without disabilities proportion distribution by extended instruction level

\begin{tabular}{|c|c|c|c|c|c|c|c|c|c|c|}
\hline & \multicolumn{10}{|c|}{ EXTENDED INSTRUCTION LEVEL } \\
\hline & NIA1 & NIA2 & NIA3 & NIA4 & NIA5 & NIA6 & NIA7 & NIA8 & NIA9 & NIA10 \\
\hline \multirow{3}{*}{$\begin{array}{l}\text { DISABLED } \\
\text { PEOPLE }\end{array}$} & 1321562 & 6227212 & 2892204 & 1346599 & 2937581 & 718487 & 135715 & 31465 & 11626 & 77005 \\
\hline & $8.42 \%$ & $39.67 \%$ & $18.42 \%$ & $8.58 \%$ & $18.71 \%$ & $4.58 \%$ & $0.86 \%$ & $0.20 \%$ & $0.07 \%$ & $0.49 \%$ \\
\hline & $55.48 \%$ & $78.97 \%$ & $\mathbf{7 3 . 3 3 \%}$ & $84.13 \%$ & $81.49 \%$ & $79.65 \%$ & $79.65 \%$ & $79.67 \%$ & $\mathbf{7 7 . 8 6 \%}$ & $84.13 \%$ \\
\hline & 1060536 & 1658267 & 1051896 & 254068 & 667131 & 183579 & 34681 & $\mathbf{8 0 2 7}$ & 3306 & 14525 \\
\hline DISAI & $21.49 \%$ & $33.60 \%$ & $21.31 \%$ & $5.15 \%$ & $13.52 \%$ & $3.72 \%$ & $0.70 \%$ & $0.16 \%$ & $0.07 \%$ & $0.29 \%$ \\
\hline PEOPLE & $44.52 \%$ & $21.03 \%$ & $26.67 \%$ & $15.87 \%$ & $18.51 \%$ & $20.35 \%$ & $20.35 \%$ & $20.33 \%$ & $22.14 \%$ & $15.87 \%$ \\
\hline
\end{tabular}

Continuing, Figure 10 shows a distribution table and profile diagram for income level by education level for people with and without disabilities. Note that disabled people group has a lower income than without disabled people up to the NIA5 level. While the situation reverses from the NIA6 level or more. 


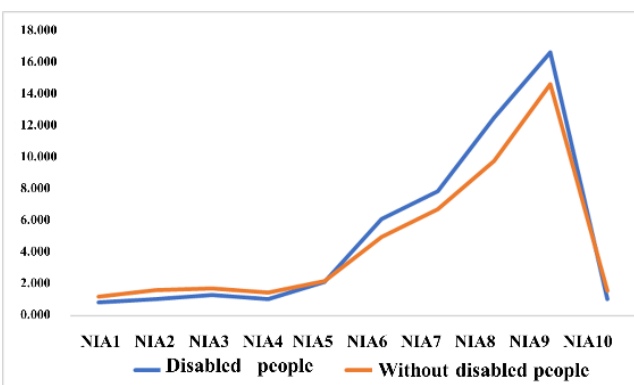

\begin{tabular}{|c|c|c|c|c|c|}
\hline $\begin{array}{l}\text { Extended } \\
\text { instruction } \\
\text { level }\end{array}$ & ription & frequency & $(\%)$ & $\begin{array}{c}\text { Disabled } \\
\text { people }\end{array}$ & $\begin{array}{l}\text { Without } \\
\text { disabled } \\
\text { people }\end{array}$ \\
\hline NIA1 & Without instruction & 382098 & 11.54 & 0.842 & 1.208 \\
\hline NIA2 & Until the fifth year of elementary school & 7885479 & 38.21 & 1.077 & 1.648 \\
\hline NIA3 & incomplete elen & 3944100 & 19.11 & 1.337 & 1.732 \\
\hline NIA4 & $\begin{array}{r}\text { Complete element } \\
\text { incomplete mi }\end{array}$ & 1600667 & 7.76 & 1.049 & 1.451 \\
\hline NIA5 & $\begin{array}{l}\text { Between complet } \\
\text { incomplete hig }\end{array}$ & & 17.47 & 2.166 & 2.196 \\
\hline NIA6 & $\begin{array}{l}\text { between complete higher education and } \\
\text { incomplete master's }\end{array}$ & 12066 & 4.37 & $\mid 6.095$ & 4.988 \\
\hline & & & & & \\
\hline NIA8 & $\begin{array}{r}\text { Between full ma } \\
\text { do }\end{array}$ & 492 & 0.19 & 12.513 & 9.797 \\
\hline & & & & 6.645 & \\
\hline & & 01530 & 0.44 & 1.055 & \\
\hline
\end{tabular}

Figure 10 - Profiles Diagram and income distribution for people with and without disabilities for extended instruction level.

This result shows that disabled people can present better conditions for obtaining higher income when their education level is higher and even under conditions of equality with people who do not have disabilities.

Continuing in Figure 10, with regard to the population distribution by education level, it is possible to observe a higher proportion of NIA2 with $38.21 \%$ and the lowest is NIA9 with $0.07 \% ; 68.85 \%$ is made up of people who have at least an incomplete fundamental education level (NIA1 + NIA2 + NIA3); on the other hand, for complete higher education levels or more (NIA6 + NIA7 + NIA8 + NIA9) they represent only $5.47 \%$ of the population, and finally; $25.23 \%$ of the population has education level between complete elementary school and incomplete higher education (NIA4 + NIA5).

Table 4 illustrates the proportions distribution for people with and without disabilities by education level.

Also, in Table 4, when researching the results obtained comparatively between the distributions of people with and without disabilities for NIA, it is concluded that disabled people have higher proportions of NIA2, NIA4, NIA5, NIA6, NIA7 and NIA8. These results reflect the greatest difficulties on the disabled people to obtain a better instruction level.

In sequence, Figure 11 shows the income distribution by main job type for people with and without disabilities.

Table 5 - People with and without disabilities proportion distribution by main work type

\begin{tabular}{|c|c|c|c|c|c|c|c|}
\hline & \multicolumn{7}{|c|}{ WORK MAIN TYPE } \\
\hline & TT1 & TT2 & TT3 & TT4 & TT5 & TT6 & TT7 \\
\hline \multirow{3}{*}{$\begin{array}{c}\text { WITHOUT } \\
\text { DISABLED } \\
\text { PEOPLE }\end{array}$} & 2965742 & 384367 & 1537821 & 1485598 & 128741 & 139062 & 350283 \\
\hline & $42.42 \%$ & $5.50 \%$ & $22.00 \%$ & $21.25 \%$ & $1.84 \%$ & $1.99 \%$ & $5.01 \%$ \\
\hline & $81.10 \%$ & $76.12 \%$ & $76.30 \%$ & $71.93 \%$ & $80.58 \%$ & $73.57 \%$ & $62.60 \%$ \\
\hline \multirow{3}{*}{$\begin{array}{l}\text { DISABLED } \\
\text { PEOPLE }\end{array}$} & 691185 & 120589 & 477661 & 579830 & 31029 & 49958 & 209241 \\
\hline & $32.01 \%$ & $5.58 \%$ & $22.12 \%$ & $26.85 \%$ & $1.44 \%$ & $2.31 \%$ & $9.69 \%$ \\
\hline & $18.90 \%$ & $23.88 \%$ & $23.70 \%$ & $28.07 \%$ & $19.42 \%$ & $26.43 \%$ & $37.40 \%$ \\
\hline
\end{tabular}




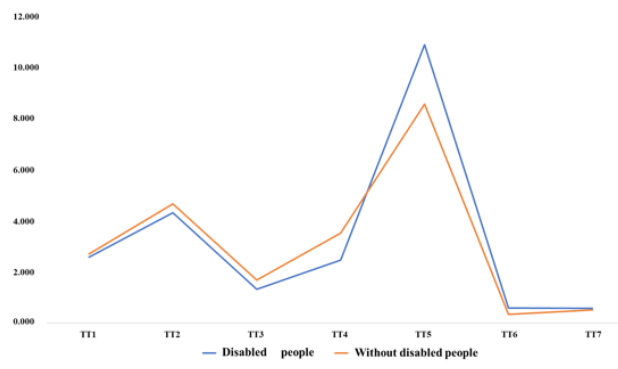

\begin{tabular}{c|c|c|c|c|c}
\hline $\begin{array}{c}\text { Main } \\
\text { work type }\end{array}$ & description & frequency & $(\%)$ & $\begin{array}{c}\text { Disabled } \\
\text { people }\end{array}$ & $\begin{array}{c}\text { Without } \\
\text { disabled } \\
\text { people }\end{array}$ \\
\hline TT1 & $\begin{array}{c}\text { work with a } \\
\text { formal contract }\end{array}$ & 3656927 & 39.962 & 2.580 & 2.707 \\
\hline TT2 & $\begin{array}{c}\text { public or } \\
\text { militarv servant }\end{array}$ & 504956 & 5.518 & 4.326 & 4.678 \\
\hline TT3 & own account & 2015482 & 22.024 & 1.332 & 1.693 \\
\hline TT4 & informal work & 2065428 & 22.570 & 2.466 & 3.536 \\
\hline TT5 & Employer & 159770 & 1.746 & 10.915 & 8.586 \\
\hline TT6 & unpaid work & 189020 & 2.066 & 0.588 & 0.342 \\
\hline TT7 & $\begin{array}{c}\text { production or } \\
\text { consumption }\end{array}$ & 559524 & 6.114 & 0.583 & 0.519 \\
\hline
\end{tabular}

Figure 11 - Profiles Diagram and income distribution for people with and without disabilities for main work type.

Analyzing Figure 11, it was possible to verify that disabled people have lower income when compared to people without disabilities, with the exception of employers, unpaid work and in the production itself for consumption. This reflects the fact that disabled people are in lower-income situations with the exception of employers.

Table 5 shows proportions distribution for people with and without disabilities by main work type.

In Table 5, when comparing the distributions of people with and without disabilities by type of main job, it shows that disabled people have higher proportions for TT2, TT3, TT4, TT6 and TT7.

Analyzing the figures 8 to 11 together, it is possible to verify that disabled people compared without disabled people the variables expanded education level (Figure 10) for levels NIA7, NIA8 and NIA9, and finely; work main type (Figure 11) for levels TT5, TT6 and TT7.

It is believed that a lower proportion for TT1 reflects the greater difficulties of disabled people in finding a formal job and, consequently, forced into situations with worse working relationships such as TT3, TT4, TT6 and TT7 except TT5.

Figure 12 shows the distributions by simple type disability in the population formed by the respondents to the full questionnaire of the 2010 IBGE census. It can be seen in this figure that the largest number of people among the different disabilities is made up of visual disabled people represent $77.9 \%$ of people with at least one disability and that $28 \%$ of disabled people are disabled multiple people. 


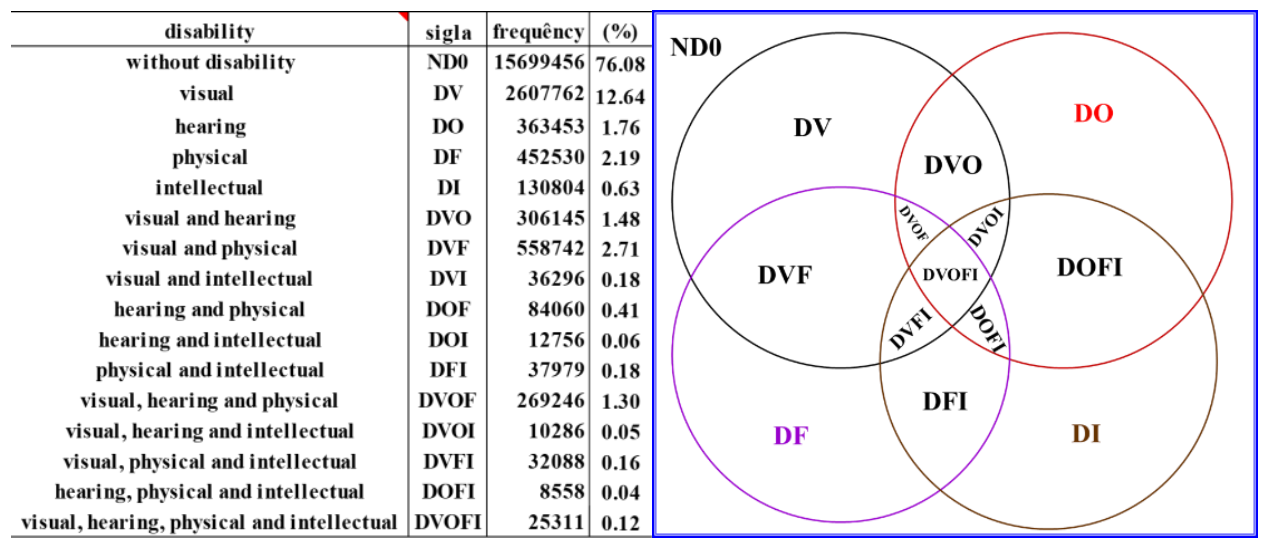

Figure 12 - Frequency table and distribution chart by disability types in the population.

Step 2: we cross between two variables for visual disability and extended education level (Table 6), between number disabilities number (ND) and expanded education level (NIA) (Table 7), between DV and NR (Table 8) and between DV and NF (Table 9).

Table 6 shows results of crossing between the variables visual disability (DV) and expanded education level (NIA). Note that for DV it contains the levels you cannot see at all (DV1 with $0.2 \%$ of the population); can see, but with great difficulty (DV2 with 3.3\%), can see, but with a little difficulty (DV3 with 15.1\%), and finally; he has no problem seeing (DV4 with $81.3 \%$ ), and, for NIA, it has the following levels: NIA1 with $11.54 \%$; NIA2 $38.21 \%$, NIA3 19.11\%; NIA4 7.76\%; NIA5 17.47\%; NIA6 4.37\%; NIA7 constituted by $0.83 \%$; NIA8 $0.19 \%$; NIA9 with only $0.07 \%$, and finally; NIA 10 with $0.44 \%$.

Studying Table 6, it is possible to observe that visual disability people DV2 type when compared to the group formed by DV1 are more numerous at all levels of education and have a higher proportion of people with incomplete fundamental education at most (NIA1 + NIA2 + NIA3) and have lower proportions of people with complete fundamental or more. This result shows greater difficulties for DV2 to achieve a better education level than DV1.

Next, Table 7 shows the crossing between the variables visual disability (DV) and work main type (TT) shows the TT1 level, consisting of 39.96\%; TT2, 5.51\%; TT3, $22.02 \%$; TT4, $22.57 \%$; TT5, $1.74 \%$; TT6, $2.07 \%$, and, finally; TT7 with $6.11 \%$ and DV with the same data already mentioned in Table 6.

Examining Table 7, it was possible to verify that DV2 when compared to DV1 shows that DV2 presents a much larger number of people at all levels, however, DV2 presents lower proportions for TT1, TT2 and TT5 and greater proportions for TT3, TT4, TT6 and TT7.

It is public knowledge that the functions that tend to have better working conditions and pay are those related to TT1, TT2 and TT5 and the most deteriorated conditions are TT6 and TT7 followed by the order of TT4 and TT3, which usually offer reasonable in terms financial gain and precarious conditions in terms of labour relations and rights. 
Table 6 - Intersection between the variables visual disability (DV) and extended education level (NIA)

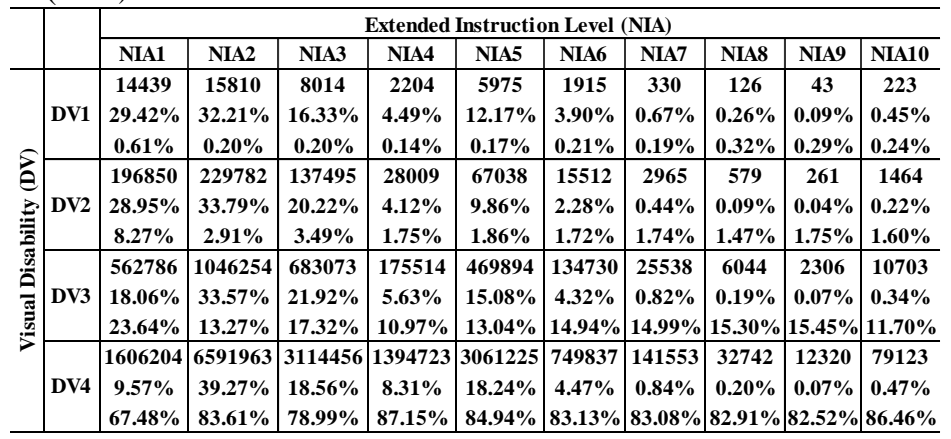

Table 7 - Intersection between the variables visual disability (DV) and Main work type (TT)

\begin{tabular}{|c|c|c|c|c|c|c|c|c|}
\hline & & \multicolumn{7}{|c|}{ Main work type (TT) } \\
\hline & & TT1 & TT2 & TT3 & TT4 & TT5 & TT6 & TI7 \\
\hline \multirow{12}{*}{ 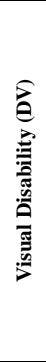 } & & 6148 & 724 & 2679 & 3180 & 306 & 308 & 691 \\
\hline & DV1 & $43.80 \%$ & $5.16 \%$ & $19.09 \%$ & $22.66 \%$ & $2.18 \%$ & $2.19 \%$ & $4.92 \%$ \\
\hline & & $0.17 \%$ & $0.14 \%$ & $0.13 \%$ & $0.15 \%$ & $0.19 \%$ & $0.16 \%$ & $0.12 \%$ \\
\hline & & 71031 & 12556 & 63440 & 72457 & 2602 & 7011 & 33253 \\
\hline & DV2 & $27.07 \%$ & $4.79 \%$ & $24.18 \%$ & $27.62 \%$ & $0.99 \%$ & $2.67 \%$ & $12.68 \%$ \\
\hline & & $1.94 \%$ & $2.49 \%$ & $3.15 \%$ & $3.51 \%$ & $1.63 \%$ & $3.71 \%$ & $5.94 \%$ \\
\hline & & 491189 & 88434 & 329715 & 402824 & 21852 & 32601 & 136778 \\
\hline & DV3 & $32.67 \%$ & $5.88 \%$ & $21.93 \%$ & $26.79 \%$ & $1.45 \%$ & $2.17 \%$ & $9.10 \%$ \\
\hline & & $13.44 \%$ & $17.51 \%$ & $16.36 \%$ & $19.51 \%$ & $13.68 \%$ & $17.25 \%$ & $24.45 \%$ \\
\hline & & 3087497 & 403194 & 1619370 & 1586492 & 134995 & 149087 & 388799 \\
\hline & DV4 & $41.90 \%$ & $5.47 \%$ & $21.97 \%$ & $21.53 \%$ & $1.83 \%$ & $2.02 \%$ & $5.28 \%$ \\
\hline & & $84.45 \%$ & $79.85 \%$ & $80.36 \%$ & $76.83 \%$ & $84.50 \%$ & $\mathbf{7 8 . 8 8 \%}$ & $69.49 \%$ \\
\hline
\end{tabular}

Under this scenario, it is possible to conclude that DV2, although they are in greater numbers, usually present more precarious working conditions than DV1.

Table 8 shows the results for the cross between the variables visual disability (DV) and income level (NR). Note that NR has level between zero and one minimum wage (NR1 representing 64.7\%), between one and three minimum wages (NR2 with $25.8 \%$ ), between 7 and 15 minimum wages (NR4 with 2.0\%) and 15 minimum wages or more (NR5 with $0.9 \%$ ) and DV with the same levels and values mentioned in Table 6.

From the analysis of Table 7 comparing DV1 and DV2 it was possible to verify that DV2 has a greater number of people than DV1, has greater proportions for NR1 and NR2, and lower proportions for NR3, NR4 and NR5.

According to these results, it concludes that DV1 presents better conditions in terms of income than DV2. Finally, Table 9 illustrates the results for the cross between the variables visual disability (DV) and sons' number (NF). Note that NF has not son levels (NF1 with 43.2\%), between one and two sons (NF2 with 34.2\%), between 3 and 5 children (NF3 with $11.5 \%$ ) and six or more sons (NF4 with $11.1 \%$ ). 
Studying Table 9 and comparing the levels DV1 and DV2 shows that DV2 has a lower proportion for NF1 and a higher proportion for NF2, NF3 and NF4. With these results it is possible to observe that DV1 has, on average, fewer children than DV2.

Table 8 - Intersection between the variables visual disability (DV) and Income Level (NR)

\begin{tabular}{|c|c|c|c|c|c|c|}
\hline & & \multicolumn{5}{|c|}{ INCOME LEVEL (mw) } \\
\hline & & NR1 & NR2 & NR3 & NR4 & NR5 \\
\hline \multirow{12}{*}{ 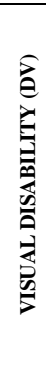 } & \multirow{3}{*}{ DV1 } & 31265 & 9859 & 2578 & 925 & 431 \\
\hline & & $69.39 \%$ & $21.88 \%$ & $5.72 \%$ & $2.05 \%$ & $0.96 \%$ \\
\hline & & $0.28 \%$ & $0.22 \%$ & $0.22 \%$ & $0.26 \%$ & $0.27 \%$ \\
\hline & \multirow{3}{*}{ DV2 } & 473490 & 153463 & 29276 & 7190 & 2822 \\
\hline & & $71.07 \%$ & $23.03 \%$ & $4.39 \%$ & $1.08 \%$ & $0.42 \%$ \\
\hline & & $4.20 \%$ & $3.42 \%$ & $2.54 \%$ & $2.04 \%$ & $1.78 \%$ \\
\hline & \multirow{3}{*}{ DV3 } & 1952928 & 786870 & 204548 & 60975 & 26976 \\
\hline & & $64.40 \%$ & $25.95 \%$ & $6.75 \%$ & $2.01 \%$ & $0.89 \%$ \\
\hline & & $17.34 \%$ & $17.53 \%$ & $17.71 \%$ & $17.26 \%$ & $17.02 \%$ \\
\hline & \multirow{3}{*}{ DV4 } & 8803955 & 3537326 & 918299 & 284150 & 128285 \\
\hline & & $64.39 \%$ & $25.87 \%$ & $6.72 \%$ & $2.08 \%$ & $0.94 \%$ \\
\hline & & $78.18 \%$ & $\mathbf{7 8 . 8 3 \%}$ & $79.53 \%$ & $80.44 \%$ & $80.93 \%$ \\
\hline
\end{tabular}

Table 9 - Intersection between the variables visual disability (DV) and Sons number (NF)

\begin{tabular}{|c|c|c|c|c|c|}
\hline & & \multicolumn{4}{|c|}{ SONS NUMBER (NF) } \\
\hline & & NF1 & NF2 & NF3 & NF4 \\
\hline \multirow{12}{*}{ 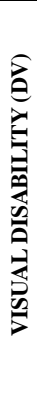 } & & 6831 & 6092 & 2823 & 5139 \\
\hline & DV1 & $32.71 \%$ & $29.17 \%$ & $13.52 \%$ & $24.61 \%$ \\
\hline & & $0.21 \%$ & $0.24 \%$ & $0.33 \%$ & $0.61 \%$ \\
\hline & & 63125 & 111091 & 68737 & 113299 \\
\hline & DV2 & $17.72 \%$ & $31.18 \%$ & $19.29 \%$ & $31.80 \%$ \\
\hline & & $1.95 \%$ & $4.32 \%$ & $7.95 \%$ & $13.55 \%$ \\
\hline & & 384147 & 569759 & 266059 & 324218 \\
\hline & DV3 & $24.88 \%$ & $36.90 \%$ & $17.23 \%$ & $21.00 \%$ \\
\hline & & $11.84 \%$ & $22.16 \%$ & $30.78 \%$ & $38.76 \%$ \\
\hline & & 2791125 & 1884507 & 526724 & 393733 \\
\hline & DV4 & $49.88 \%$ & $33.68 \%$ & $9.41 \%$ & $7.04 \%$ \\
\hline & & $86.01 \%$ & $73.29 \%$ & $60.94 \%$ & $47.08 \%$ \\
\hline
\end{tabular}

Step 3: The fertility index per woman for variables disability type by federation unit (UF) in Table 10; for the extended instruction level (NIA), race (RA) and zone (ZO) in Table 11; for main work type (TT), disability (pcd) and income level (NR) in Table 12, and finally; minimum and maximum values for the fertility index for each variable level in Table 13. Note also that the values in bold are values greater than 2.1, which means that they are the cases that guarantee population growth.

Table 10 shows the fertility rate per woman by simple disability type (tipodef) by federation unit (UF) and total.

Studying Table 10, it was observed that the highest fertility rate was for visual, hearing and physical disability (DVOF) with an index of 4.95 and the lowest was for intellectual (DI) with an index of 1.09 .

The simple disability type that did not reach a fertility index of at least 2.1 without guaranteeing a population growth were without disabilities (SD) with 1.45; intellectual (DI) 
with 1.09; visual and intellectual (DVI) with 1.92; hearing and intellectual (DOI) with 1.24, and finally; physical and intellectual disabilities with 1.83 .

When analysing the fertility index by state, it is noted that this index obtained a maximum value of 2.9 for the states of Paraíba, Piauí and Maranhão, while the lowest value was reached in the Federal District, which obtained 1.7.

It is also noted that the states that obtained a value less than 2.1 were: Rio de Janeiro, São Paulo, Rio Grande do Sul and the Federal District.

Table 10 - Fertility index by simple deficiency type (tipodef)

\begin{tabular}{|c|c|c|c|c|c|c|c|c|c|c|c|c|c|c|c|c|c|}
\hline \multirow[b]{2}{*}{ UF } & \multicolumn{16}{|c|}{ Simple disability type } & \multirow[b]{2}{*}{ TOTAI } \\
\hline & SD & DV & DO & DF & DI & DVO & DVF & DVI & DOF & DOI & DFI & DV & DV & V & ( & VOF & \\
\hline RO & 59 & 2.99 & 98 & .38 & 44 & 4.52 & 4.93 & 2.40 & 6.37 & 3.2 & 1.50 & 6.07 & 4.00 & 4.38 & 1.00 & 6.13 & 2.40 \\
\hline AC & 52 & 2.96 & .65 & 3.08 & 22 & 4. & 5.26 & 2.96 & 90 & & 3.10 & 58 & 2.82 & .14 & 0.00 & 42 & 2.61 \\
\hline AM & 43 & 2.75 & 97 & 3.89 & 6 & 3.8 & 5.1 & & 37 & & 1.48 & 6.01 & .57 & 4.62 & 4 & 3.97 & 2.56 \\
\hline $\mathbf{R R}$ & 37 & & .52 & 3.31 & & & 4.79 & & & & 1.78 & & & 4.75 & & & 2.38 \\
\hline PA & & & & & & & & & & & & & & & & & 2.58 \\
\hline $\mathbf{A P}$ & & 2.91 & 17 & 3.79 & 0.6 & & 5.32 & & & & 1.50 & & & & & & 2.53 \\
\hline TO & & & & 4.41 & & & & & & & & & & & & & 73 \\
\hline MA & 64 & 3.31 & 60 & 4.19 & 1.37 & 4.65 & 5.78 & 2.88 & & & 2.20 & & 52 & 3.95 & & & 2.87 \\
\hline PI & 1.58 & 3.09 & 2.97 & 4.36 & 1.09 & 4.74 & 5.68 & 2.28 & 5.90 & 0.85 & 1.50 & 6.67 & 4.30 & 3.86 & 3.41 & 4.47 & 2.89 \\
\hline CE & 1.47 & 2.63 & 2.66 & 4.29 & 1.18 & 4.03 & 5.08 & 70 & & & 2.21 & 6.05 & 3.15 & .90 & 4. & .37 & 2.64 \\
\hline $\mathbf{R N}$ & 1.52 & 2.71 & 2.85 & 4.50 & 1.39 & 4.15 & 5.39 & 2.04 & 60 & 1.23 & 2.74 & 52 & & .97 & & 34 & 2.73 \\
\hline PB & 1.64 & 3.02 & 36 & 4.68 & 1.15 & 4.41 & 5.59 & 2.11 & 6. & & 2.09 & & 2.37 & 4.17 & & 79 & 2.89 \\
\hline PE & 52 & 2.52 & 81 & 4.10 & 1.06 & 3.91 & 4.85 & 1.76 & & 0.77 & 2.22 & & 2.08 & 3.91 & & 4.55 & 2.53 \\
\hline $\mathbf{A L}$ & 61 & 2.96 & 2.65 & 4.33 & 1.50 & 4.04 & 5.62 & 2.78 & 5.0 & 3.0 & 2.16 & & .88 & 4.53 & 2.68 & 4.40 & 2.84 \\
\hline SE & .62 & 2.9 & 90 & 4.77 & 39 & & & & & & 1.53 & & & & & & 2.64 \\
\hline BA & & & & & & & & & & & & & & & & & 2.66 \\
\hline MG & .50 & 2.56 & .82 & 3.78 & 1.07 & 3.80 & 4.45 & 1.90 & & & 1.82 & & 2.55 & 3.17 & & & 2.30 \\
\hline ES & 1.42 & 2.41 & 2.58 & 3.70 & 1.25 & 3.53 & 4.30 & 1.64 & & & 2.06 & & 1.71 & 2.79 & & 4.50 & 2.14 \\
\hline RJ & 1.24 & 1.92 & 2.01 & 2.67 & 0.79 & 2.71 & 3.17 & & & & 1.55 & & & 2.69 & & & 1.76 \\
\hline SP & 1.36 & 2.10 & 2.35 & 3.13 & 1.03 & 3.03 & 3.66 & 1.73 & 3.76 & 1.18 & 1.76 & 3.97 & 2.20 & 2.80 & 2.53 & 3.15 & 1.87 \\
\hline PB & 1.51 & 2.66 & 2.84 & 3.79 & 1.17 & 3.90 & 4.50 & 1.95 & 4.85 & 1.05 & 1.59 & 5.15 & .70 & 3.04 & 2.52 & 3.84 & 2.26 \\
\hline SC & 1.45 & 2.55 & 2.70 & 3.70 & 0.91 & 3.84 & 4.37 & 1.74 & 4. & 0.90 & 1.75 & 5.21 & 1.93 & 3.31 & 2.33 & 4.02 & 2.12 \\
\hline RS & 1.39 & 2.33 & .52 & 3.28 & 1.02 & 3.32 & 3.77 & 1.86 & & & 1.86 & 4. & 1.99 & 3.04 & 2.60 & 3.29 & 2.02 \\
\hline MS & 1.52 & 2.66 & .55 & 3.71 & 1.35 & 3.90 & 4.56 & 2.51 & 4.5 & 2.9 & 1.87 & & 1.55 & 3.20 & 1.96 & 3.97 & 2.2 \\
\hline MT & 1.49 & 2.75 & 2.76 & 3.83 & 1.2 & 4.2 & 4.89 & 2.25 & & 1.4 & 1.37 & & 1.56 & 4.55 & 1.33 & & 2.29 \\
\hline GO & 1.59 & 2.52 & 2.73 & 3.59 & 1.27 & 3.75 & 4.32 & 1.79 & & & 2.09 & & 2.42 & 3.04 & 2.00 & 3.53 & 2.20 \\
\hline DF & 1.21 & 1.81 & 2.08 & 3.25 & 1.60 & 2.83 & 3.37 & 0.95 & 3.66 & 1.17 & 2.51 & 4.13 & 0.60 & 3.24 & 3.00 & 3.73 & 1.66 \\
\hline otal & 1.45 & 2.47 & 2.62 & 3.58 & 1.09 & 3.65 & 4.33 & 1.92 & 4.47 & 1.24 & 1.83 & 4.95 & 2.36 & 3.26 & 2.59 & 3.69 & 2.10 \\
\hline
\end{tabular}

For Brazil as a whole, an index of 2.1 was found, which means that its population remains stable.

Next, Table 11 is shown for the fertility index per woman for the variables expanded education level (NIA), race (RA) and zone (ZO).

Evaluating Table 11, it was verified that for NIA the highest fertility index was obtained for uneducated (NIA1) with 5.01 and the lowest was for (NIA4) with 0, 81; for race the lowest value was for RA1 (white) with 1.92 and the highest value was for RA5 (indigenous) with 2.62, and finally; for zone it was obtained as a result for urban zone 1.96 and rural zone 2.60 .

Further on, Table 12 presents the fertility index for the variables main work type, disabled people (PCD) and income level (NR). 
Examining Table 12, the lowest index was found for TT1 with 1.27, while the highest index was for TT7 with 3.17.

For disabled people it was observed that without disabilities (ND0) it reached an index of 1.55, while for disabled people (PCD) it had an index of 3.37 .

Table 11 - Fertility index for the variables expanded education level (NIA), race (RA) and zone ( $\mathrm{ZO})$

\begin{tabular}{|c|c|c|c|c|c|c|c|c|c|c|c|c|c|c|c|c|}
\hline & \multicolumn{9}{|c|}{ Extended instruction level (NIA) } & \multicolumn{5}{|c|}{ RaCE (RA) } & \multicolumn{2}{|c|}{ ZonE (ZO) } \\
\hline UF & NIA1 & NIA2 & NIA3 & NIA4 & NIA5 & NIA6 & NIA7 & NIA8 & NIA9 & RA1 & RA2 & RA3 & RA4 & RA5 & ZO1 & $\mathrm{ZO2}$ \\
\hline RO & 5.92 & 2.32 & 2.36 & 0.89 & 1.30 & 1.43 & 1.62 & 1.60 & 1.22 & 2.14 & 2.60 & 1.85 & 2.19 & 2.82 & 2.05 & 2.54 \\
\hline $\mathbf{A C}$ & 5.25 & 1.81 & 2.70 & & & 1.45 & 1.42 & 1.25 & 0.90 & 2.10 & 3.03 & 2.24 & 2.39 & 2.62 & 2.19 & 2.78 \\
\hline $\mathbf{A M}$ & 5.05 & 1.72 & 2.79 & & & 1.44 & & & & & & & & 2.43 & & 2.58 \\
\hline $\mathbf{R R}$ & 4.44 & 1.79 & 2.89 & 1.06 & 1.46 & 1.41 & 1.58 & 1.42 & & 1.88 & 2.57 & 2.09 & 2.11 & 2.47 & 2.01 & 2.44 \\
\hline PA & 5.28 & 2.01 & 2.73 & 1.01 & 1.41 & 1.40 & 1.41 & 1.50 & 1.04 & 2.15 & 2.65 & 2.11 & 2.35 & 2.78 & & 2.68 \\
\hline $\mathbf{A P}$ & 5.82 & 1.73 & 3.32 & 1.06 & 1.61 & 1.38 & 1.65 & 1.50 & 0.88 & 2.06 & 2.43 & 2.19 & 2.33 & 2.61 & 2.17 & 3.04 \\
\hline TO & 5.59 & 2.28 & 2.93 & 0.87 & 1.50 & 1.57 & 1.52 & 1.00 & 0.69 & 2.25 & 2.97 & 2.25 & 2.48 & 2.63 & 2.30 & 2.97 \\
\hline MA & 5.39 & 2.16 & 2.90 & 0.83 & 1.40 & 1.59 & 1.59 & 1.42 & 1.43 & 2.41 & 2.89 & 2.62 & 2.57 & 2.67 & 2.39 & 2.83 \\
\hline PI & 5.19 & 2.20 & 2.40 & 0.74 & 1.23 & 1.48 & 1.49 & 1.66 & 0.93 & 2.39 & 3.02 & 2.66 & 2.61 & 2.77 & 2.39 & 2.86 \\
\hline CE & 5.20 & 2.34 & 2.61 & 0.66 & 1.13 & 1.28 & 1.48 & 1.38 & 1.35 & 2.20 & 2.90 & 2.37 & 2.43 & 2.66 & 2.20 & 2.78 \\
\hline $\mathbf{R N}$ & 5.50 & 2.36 & 2.72 & 0.90 & 1.14 & 1.35 & 1.48 & 0.93 & 1.03 & 2.27 & 2.99 & 2.57 & 2.57 & 2.28 & 2.31 & 2.88 \\
\hline PB & 5.52 & 2.43 & 2.56 & 0.76 & 1.18 & 1.47 & 1.54 & 1.32 & 1.29 & 2.46 & 3.03 & 2.50 & 2.66 & 2.72 & 2.44 & 2.93 \\
\hline PE & 5.26 & 2.01 & 2.44 & 0.80 & 1.19 & 1.31 & 1.46 & 1.17 & 1.32 & 2.16 & 2.57 & 2.14 & 2.35 & 2.57 & 2.16 & 2.73 \\
\hline $\mathbf{A L}$ & & 1.87 & 2.52 & & & & & & & 2.38 & 3.06 & & 59 & 2.77 & & 2.87 \\
\hline SE & & 1.97 & 2.61 & 0.84 & & & 1.43 & 1.34 & 0.8 & 2.30 & 2.68 & 2.1 & 2.39 & 2.58 & 2.1 & 2.81 \\
\hline BA & 5.53 & 2.27 & 2.51 & 0.82 & 1.23 & 1.23 & 1.29 & 1.33 & 0.99 & 2.34 & 2.48 & 2.15 & 2.40 & 2.98 & 2.19 & 2.82 \\
\hline MG & 5.01 & 2.43 & 2.23 & 0.75 & 1.14 & 1.21 & 1.36 & 1.14 & 1.10 & 1.98 & 2.35 & 1.93 & 2.17 & 2.83 & 1.99 & 2.54 \\
\hline $\mathbf{E S}$ & 5.06 & 2.35 & 2.24 & 0.79 & 1.18 & 1.14 & 1.22 & 1.06 & 1.00 & 1.90 & 2.23 & 1.87 & 2.00 & 2.53 & 1.90 & 2.28 \\
\hline RJ & 4.06 & 1.79 & 2.14 & 0.90 & 1.22 & 1.10 & 1.09 & 1.12 & 1.13 & 1.57 & 1.89 & 1.56 & 1.70 & 2.29 & 1.64 & 2.12 \\
\hline SP & 4.53 & 2.08 & 2.16 & 0.81 & 1.18 & 1.09 & 1.07 & 1.00 & 1.08 & 1.70 & 1.98 & 1.67 & 1.87 & 2.43 & 1.73 & 2.16 \\
\hline PB & 5.10 & 2.46 & 2.26 & 0.83 & 1.20 & 1.1 & 1.36 & 1.16 & 1.13 & 1.98 & 2.53 & 2.07 & 2.27 & 2.85 & 1.99 & 2.42 \\
\hline SC & 4.82 & 2.53 & 2.32 & 0.76 & 1.13 & 1.02 & 1.25 & 1.05 & 1.00 & 1.91 & 2.24 & 2.01 & 2.21 & 2.68 & 1.84 & 2.35 \\
\hline RS & 4.27 & 2.20 & 2.30 & 0.78 & 1.06 & 1.10 & 1.25 & 0.95 & 1.16 & 1.82 & 2.07 & 2.30 & 2.15 & 2.64 & 1.76 & 2.23 \\
\hline MS & 5.23 & 2.18 & 2.44 & & 1.32 & 1.28 & 1.39 & 1.15 & 1.41 & 1.98 & 2.37 & 1.88 & 2.17 & 2.54 & 2.05 & 2.30 \\
\hline MT & 5.40 & 2.21 & 2.50 & & 1.31 & 1.30 & 1.56 & 1.52 & 1.20 & 2.00 & 2.44 & 1.93 & 2.14 & 2.63 & 2.03 & 2.40 \\
\hline GO & 4.87 & 2.20 & 2.37 & 0.93 & 1.32 & 1.28 & 1.49 & 1.27 & 1.13 & 1.97 & 2.39 & 1.74 & 2.06 & 2.92 & 1.98 & 2.36 \\
\hline DF & 4.18 & 1.55 & 2.48 & 0.93 & 1.29 & 1.21 & 1.27 & 1.07 & 1.26 & 1.51 & 1.59 & 1.54 & 1.61 & 2.45 & 1.55 & 1.98 \\
\hline otal & 5.02 & 2.23 & 2.31 & 0.81 & 1.18 & 1.16 & 1.27 & 1.09 & 1.12 & 1.92 & 2.39 & 2.03 & 2.25 & 2.62 & 1.96 & 2.60 \\
\hline
\end{tabular}

Finally, for income level (NR) the lowest value was obtained for income level between 7 and 15 minimum wages (NR4) with 1.66 and the highest was for income level between 1 and 3 minimum wages (NR2) with 2.24.

Also note that they guarantee population growth (fertility index greater than 2.1) were for the following situations: work in production for own consumption (TT7), disabled people (PCD) and income level between one to three wages minimum (NR2).

Then comes Table 13, which presents the minimum, maximum and amplitude $(\Delta)$ values for the fertility index for the levels of the variables simple disability type (tipodef), expanded education level (NIA), race (RA), zone (ZO), main work type (TT), disabled people (PCD) and income level (NR) between the different units of the federation. 
Examining Table 13, it is possible to verify the occurrence of variability between states, with the highest amplitude being found for DOFI between (AP or AC) and CE in the value of 4.10 and the lowest was for NIA4 between $\mathrm{CE}$ and $\mathrm{AC}$ with an amplitude 0.42 .

Step 4: Distribution of the income level to the levels of the following variables: disability type (Table 14), expanded education level, race and zone (Table 15), disability and main work type (Table 16).

The next one is Table 14 shows the distribution of income level for simple disability type (tipodef) with a strong predominance of income level between zero and one minimum wage (NR1) in all its levels and it is also verified that the highest proportion income between one and three minimum wages (NR2) was $27.1 \%$ in the DVO, for income level between 3 and 7 minimum wages (NR3) was $8.2 \%$, NR4 was $2.5 \%$ and for NR5 it was $1.2 \%$ in DO.

Table 12 - Fertility index for main work type (TT), disability (PCD) and income level (NR)

\begin{tabular}{|c|c|c|c|c|c|c|c|c|c|c|c|c|c|c|}
\hline & \multicolumn{7}{|c|}{ Main Work Type (TT) } & \multicolumn{2}{|c|}{ Disability } & \multicolumn{5}{|c|}{ Income level (NR) } \\
\hline UF & TT1 & TT2 & TT3 & TT4 & TT5 & TT6 & $\mathbf{T T}$ & ped & Npcd & NR1 & NR2 & NR3 & NR4 & NR5 \\
\hline RO & 1.52 & 1.84 & 1.91 & 2.37 & 2.03 & 1.98 & 2.9 & 3.69 & 1.63 & 2.10 & 2.59 & 2.11 & 1.98 & 1.98 \\
\hline AC & 1.89 & 1.78 & 1.94 & 2.80 & 2.41 & 2.18 & 3.6 & 3.97 & 1.70 & 2.21 & 3.18 & 2.23 & 2.17 & 2.02 \\
\hline AM & 1.52 & 2.07 & 2.19 & 2.88 & 1.89 & 1.78 & 3.7 & 3.92 & 1.64 & 2.20 & 2.88 & 2.19 & 1.86 & 1.95 \\
\hline $\mathbf{R R}$ & 1.53 & 1.78 & 1.90 & 2.75 & 2.71 & 1.76 & 3.2 & 3.45 & 1.63 & 2.00 & 2.72 & 2.34 & 1.95 & 1.92 \\
\hline PA & 1.46 & 1.98 & 2.04 & 2.77 & 2.04 & 2.10 & 3.3 & 3.90 & 1.64 & 2.24 & 2.99 & 2.20 & 2.04 & 1.89 \\
\hline $\mathbf{A P}$ & 1.89 & 2.06 & 2.16 & 2.87 & 2.24 & 1.84 & 4.1 & 3.77 & 1.60 & 2.11 & 3.03 & 2.44 & 2.33 & 2.17 \\
\hline TO & 1.41 & 1.97 & 1.90 & 2.54 & 2.01 & 2.18 & 3.4 & 4.10 & 1.78 & 2.42 & 2.89 & 1.93 & 1.91 & 1.92 \\
\hline MA & 1.46 & 2.08 & 1.93 & 3.06 & 2.22 & 2.30 & 3.7 & 4.16 & 1.78 & 2.45 & 3.54 & 2.26 & 2.14 & 2.00 \\
\hline PI & 1.69 & 1.78 & 1.69 & 2.67 & 2.06 & 2.10 & 3.3 & 4.18 & 1.71 & 2.43 & 3.90 & 2.32 & 2.05 & 2.29 \\
\hline $\mathbf{C E}$ & 1.32 & 1.70 & 1.63 & 2.35 & 2.12 & 1.88 & 3.3 & 3.76 & 1.62 & 2.28 & 3.16 & 1.94 & 1.87 & 2.01 \\
\hline $\mathbf{R N}$ & 1.47 & 1.78 & 1.60 & 2.28 & 1.75 & 1.93 & 3.5 & 3.85 & 1.68 & 2.36 & 3.20 & 2.12 & 2.11 & 2.05 \\
\hline PB & 1.53 & 1.91 & 1.69 & 2.47 & 2.11 & 2.05 & 3.5 & 4.08 & 1.77 & 2.46 & 3.70 & 2.23 & 2.12 & 2.25 \\
\hline PE & 1.29 & 1.67 & 1.66 & 2.26 & 2.02 & 2.10 & 3.4 & 3.51 & 1.64 & 2.23 & 2.82 & 1.94 & 1.85 & 2.01 \\
\hline $\mathbf{A L}$ & 1.72 & 1.98 & 1.88 & 2.66 & 2.26 & 2.15 & 3.4 & 4.05 & 1.75 & 2.47 & 3.40 & 2.19 & 2.13 & 2.35 \\
\hline SE & 1.53 & 1.86 & 1.90 & 2.47 & 2.22 & 2.19 & 3.6 & 3.80 & 1.69 & 2.28 & 3.18 & 2.08 & 2.06 & 2.24 \\
\hline BA & 1.38 & 1.73 & 1.75 & 2.53 & 1.93 & 2.16 & 3.5 & 3.81 & 1.73 & 2.33 & 3.01 & 1.86 & 1.73 & 1.71 \\
\hline MG & 1.25 & 1.59 & 1.69 & 1.97 & 1.77 & 2.04 & 3.2 & 3.43 & 1.57 & 2.06 & 2.33 & 1.80 & 1.82 & 1.80 \\
\hline ES & 1.19 & 1.42 & 1.74 & 2.02 & 1.69 & 1.86 & 2.7 & 3.17 & 1.47 & 1.97 & 2.07 & 1.70 & 1.72 & 1.76 \\
\hline RJ & 1.17 & 1.35 & 1.64 & 1.70 & 1.61 & 1.56 & 2.9 & 2.49 & 1.30 & 1.64 & 1.78 & 1.57 & 1.45 & 1.49 \\
\hline SP & 1.21 & 1.49 & 1.72 & 1.78 & 1.67 & 1.78 & 2.9 & 2.69 & 1.40 & 1.81 & 1.74 & 1.53 & 1.43 & 1.46 \\
\hline PB & 1.38 & 1.59 & 1.77 & 2.18 & 1.81 & 1.90 & 3.0 & 3.42 & 1.57 & 2.06 & 2.20 & 1.79 & 1.76 & 1.83 \\
\hline SC & 1.29 & 1.45 & 1.70 & 2.14 & 1.70 & 1.90 & 3.1 & 3.28 & 1.48 & 1.96 & 2.01 & 1.78 & 1.73 & 1.77 \\
\hline RS & 1.22 & 1.40 & 1.63 & 2.04 & 1.61 & 1.79 & 2.7 & 2.93 & 1.42 & 1.81 & 2.05 & 1.73 & 1.66 & 1.68 \\
\hline MS & 1.43 & 1.65 & 1.84 & 2.24 & 1.93 & 2.03 & 3.0 & 3.40 & 1.61 & 2.09 & 2.20 & 1.79 & 1.89 & 1.95 \\
\hline MT & 1.39 & 1.75 & 1.85 & 2.26 & 1.90 & 2.02 & 3.1 & 3.47 & 1.58 & 2.11 & 2.21 & 1.83 & 1.86 & 1.87 \\
\hline GO & 1.36 & 1.77 & 1.75 & 2.09 & 1.90 & 1.90 & 3.0 & 3.20 & 1.54 & 2.00 & 2.23 & 1.86 & 1.88 & 1.90 \\
\hline DF & 1.23 & 1.37 & 1.55 & 1.89 & 1.72 & 1.62 & 2.7 & 2.36 & 1.25 & 1.49 & 1.67 & 1.64 & 1.61 & 1.65 \\
\hline Total & 1.27 & 1.58 & 1.72 & 2.07 & 1.75 & 1.91 & 3.1 & \begin{tabular}{|l|l}
3.37 \\
\end{tabular} & 1.55 & 2.09 & 2.24 & 1.75 & 1.66 & 1.68 \\
\hline
\end{tabular}

From Table 14, it is possible to show that the levels considered most vulnerable show the worst income distribution (highest proportion of NR1 and lowest of NR5).

Table 15 illustrates the distributions of the income level for NIA, RA and ZO which, in the case of the variable NIA, note a strong predominance of NR1 to NIA1, NIA2, NIA3, 
NIA4, NIA5; NR2 domain to NIA6; NR3 domain to NIA7; NR4 domain to NIA8 and NR5 domain to NIA9.

Analysing Table 15 it appears that as the instruction level increases, the proportion of NR1 decreases and the proportions of NR4 and NR5 increase.

Table 16 shows that considering disabled and without disabled people with a strong predominance of NR1.

Table 13 - Minimum and maximum fertility index values per federation unit (UF)

\begin{tabular}{|c|c|c|c|c|c|c|c|c|c|c|c|c|c|c|c|c|c|}
\hline var & UF & MIN. & UF & $\max$ & $\Delta$ & var & UF & MIN. & $\mathbf{U F}$ & $\max$ & $\Delta$ & var & UF & MIN. & UF & $\max$ & $\Delta$ \\
\hline ND0 & $\mathrm{DF}$ & 1.21 & BA & 1.67 & 0.46 & DTAL & DF & 1.70 & PB. PI e MA & 2.90 & 1.20 & $\mathrm{ZO} 2$ & DF & 1.98 & $\mathrm{AP}$ & 3.04 & 1.06 \\
\hline DV & DF & 1.81 & MA & 3.31 & 1.50 & NIA1 & RJ & 4.06 & RO & 5.92 & 1.86 & TT1 & RJ & 1.17 & $\mathrm{APe} \mathrm{AC}$ & 1.89 & 0.72 \\
\hline DO & $\mathrm{AM}$ & 1.97 & TO & 3. & 1.37 & NIA2 & DF & 1.55 & & 53 & 0.98 & TT2 & $\mathrm{DF}$ & 37 & A & 2.08 & 0.71 \\
\hline DF & RJ & 2.67 & SE & 4.77 & 2.10 & NIA3 & RJ & 2.14 & TO & 2.93 & 0.79 & TT3 & DF & 1.55 & AM & 2.19 & 0.64 \\
\hline DI & AP & 0.65 & $\mathrm{AC}$ & 2.22 & 1.57 & NIA4 & $\mathrm{CE}$ & 0.66 & A & 1.08 & 0.42 & TT4 & RJ & 1.70 & MA & 3.06 & 1.36 \\
\hline DVO & RJ & 2.71 & TO & 4.75 & 2.04 & NIA5 & RS & 1.06 & AP & 1.61 & 0.55 & TT5 & RS e RJ & 1.61 & $\mathrm{R}$ & 2.71 & 1.10 \\
\hline DVF & RJ & 3.17 & MA & 5.78 & 2.61 & NIA6 & $\mathrm{SC}$ & 1.02 & MA & 1.59 & 0.57 & TT6 & RJ & 1.56 & MA & 2.30 & 0.74 \\
\hline DVI & DF & 0.95 & PR & 4.00 & 3.05 & NIA7 & SP & 1.07 & $\mathrm{AP}$ & 1.65 & 0.58 & TT7 & DFe RS & 2.70 & $\mathrm{AP}$ & 4.13 & 1.43 \\
\hline DOF & RJ & 2.97 & RO & 6.37 & 3.40 & NIA8 & $\mathrm{RN}$ & 0.93 & PI & 1.66 & 0.73 & PCD & DF & 2.26 & & 4.18 & 1.92 \\
\hline DOI & $\mathrm{APe}$ RR & 0 & RO & 3.22 & 3.22 & NIA9 & TO & 0.69 & AL & 2.00 & 1.31 & SD & DF & 1.25 & TO e MA & 1.78 & 0.53 \\
\hline DFI & MT & 1.37 & $\mathrm{AC}$ & 3.10 & 1.73 & RA1 & DF & 1.5 & $\mathrm{~PB}$ & 2.46 & 0.95 & NR1 & DF & 1.49 & PB & 2.46 & 0.97 \\
\hline DVOF & RJ & 3.57 & $\mathrm{AP}$ & 6.83 & 3.26 & RA2 & DF & 1.59 & $\mathrm{AC}$ & 3.03 & 1.44 & NR2 & DF & 1.67 & PI & 3.9 & 2.23 \\
\hline DVOI & DF & 0.66 & PI & 4.30 & 3.64 & RA3 & DF & 1.54 & & 2.66 & 1.12 & NR3 & SP & 1.53 & $\mathrm{AP}$ & 2.44 & 0.91 \\
\hline DVFI & RJ & 2.69 & AC & 5. & 2.45 & RA4 & DF & 1.61 & & 66 & 1.05 & NR4 & SF & 1.43 & A & 2.33 & 0.90 \\
\hline DOFI & $\mathrm{APe} A \mathrm{C}$ & 0 & CE & 4.10 & 4.10 & RA5 & RN & 2.28 & $\mathrm{~B} A$ & 2.98 & 0.70 & NR5 & SP & 1.46 & AL & 2.35 & 0.89 \\
\hline DVOF & AP & 2.33 & RO & 6.13 & 3.80 & ZO1 & DF & 1.55 & PB & 2.44 & 0.89 & & & & & & \\
\hline
\end{tabular}

Table 14 - Distribution of income level for disability simple type

\begin{tabular}{|c|c|c|c|c|c|c|}
\hline & \multicolumn{5}{|c|}{ Income level } \\
\hline & & NR1 & NR2 & NR3 & NR4 & NR5 \\
\hline \multirow{16}{*}{$\begin{array}{l}0 \\
0 \\
0 \\
0\end{array}$} & SD & $64.2 \%$ & $26.0 \%$ & $6.7 \%$ & $2.1 \%$ & $0.9 \%$ \\
\hline & & $.4 \%$ & $26.4 \%$ & $7.1 \%$ & $2.2 \%$ & 1.0 \\
\hline & DO & $9.6 \%$ & $28.5 \%$ & $8.2 \%$ & $2.5 \%$ & $1.2 \%$ \\
\hline & D & $65.1 \%$ & $25.8 \%$ & $6.5 \%$ & $1.8 \%$ & $0.8 \%$ \\
\hline & DI & $3.5 \%$ & $9.1 \%$ & $1.8 \%$ & $0.5 \%$ & $0.2 \%$ \\
\hline & DVO & $63.6 \%$ & 27.1 & $6.7 \%$ & $1.8 \%$ & $0.8 \%$ \\
\hline & DVF & $71.2 \%$ & $23.1 \%$ & $4.4 \%$ & $1.0 \%$ & $0.4 \%$ \\
\hline & DVI & $83.5 \%$ & $13.0 \%$ & $2.7 \%$ & $0.6 \%$ & $0.3 \%$ \\
\hline & DOF & $63.5 \%$ & $26.7 \%$ & $6.9 \%$ & $2.0 \%$ & $0.9 \%$ \\
\hline & DOI & $88.2 \%$ & $9.4 \%$ & $1.7 \%$ & $0.5 \%$ & $0.2 \%$ \\
\hline & DFI & $85.2 \%$ & 11.2 & $2.5 \%$ & $0.7 \%$ & $0.4 \%$ \\
\hline & DVOF & $71.7 \%$ & $22.7 \%$ & $4.1 \%$ & $1.0 \%$ & $0.4 \%$ \\
\hline & DVOI & $82.8 \%$ & $13.3 \%$ & $3.0 \%$ & $0.7 \%$ & $0.2 \%$ \\
\hline & & $79.7 \%$ & 16. & $3.0 \%$ & $0.7 \%$ & $0.3 \%$ \\
\hline & & & 14 & $3.2 \%$ & & $0.5 \%$ \\
\hline & DVOT & $78.7 \%$ & $16.7 \%$ & $3.4 \%$ & $0.9 \%$ & $0.4 \%$ \\
\hline
\end{tabular}

Verifying Table 16, notice that main work type, NR1 dominates for TT3, TT6 and TT7; NR2 for TT1, TT2 and TT4; and finally, NR3 for TT5. 
The highest proportion of NR1 is for TT6 with 94.7\%; NR2 went to TT1 with 60.6\%; NR3 was 31.3 for TT5; NR4 was $21.2 \%$ for TT5 and NR5 was $16.3 \%$ for TT5.

Step 5: the profile graph for main work type in Figure 13 was presented, income level in Figure 14 and instruction level in Figure 15.

The following are graphs of profiles considering different ages from year to year for disabled people (curve represented by dots), together, people with and without disabilities (curve represented by dashed lines) and without disabled people (curve represented by a continuous line).

Figure 13 shows the profiles for employees with a formal contract (in blue), military and statutory civil servants (in brown), without a formal contract (in green), own account (in orange), employers (in red), unpaid (in black) and workers in production for their own consumption (in pink).

Table 15 - Distribution of income level, expanded instruction level, race and, zone

\begin{tabular}{|c|c|c|c|c|c|c|}
\hline & \multicolumn{5}{|c|}{ Income level (NR) } \\
\hline & & NR1 & NR2 & NR3 & NR4 & NR5 \\
\hline \multirow{9}{*}{ 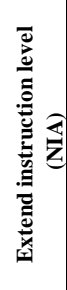 } & NIA1 & $84.8 \%$ & $14.3 \%$ & $0.8 \%$ & $0.1 \%$ & $0.0 \%$ \\
\hline & NIA2 & $80.2 \%$ & $16.5 \%$ & $2.7 \%$ & $0.5 \%$ & $0.2 \%$ \\
\hline & NIA3 & $61.0 \%$ & $32.2 \%$ & $5.5 \%$ & $1.0 \%$ & $0.3 \%$ \\
\hline & NIA4 & $75.6 \%$ & $20.4 \%$ & $3.2 \%$ & $0.6 \%$ & $0.2 \%$ \\
\hline & NIA5 & $46.0 \%$ & $39.3 \%$ & $11.0 \%$ & $2.8 \%$ & $0.9 \%$ \\
\hline & NIA6 & $17.0 \%$ & $32.4 \%$ & $29.4 \%$ & $14.1 \%$ & $7.2 \%$ \\
\hline & NIA7 & $9.1 \%$ & $23.9 \%$ & $34.5 \%$ & $19.8 \%$ & $12.6 \%$ \\
\hline & NIA8 & $9.8 \%$ & $14.1 \%$ & $25.0 \%$ & $27.9 \%$ & $23.1 \%$ \\
\hline & NIA9 & $8.1 \%$ & $7.5 \%$ & $15.3 \%$ & $30.2 \%$ & $38.8 \%$ \\
\hline \multirow{5}{*}{ 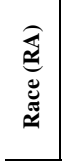 } & RA1 & $56.0 \%$ & $29.8 \%$ & $9.4 \%$ & $3.2 \%$ & $1.5 \%$ \\
\hline & RA2 & $68.5 \%$ & $25.7 \%$ & $4.5 \%$ & $1.0 \%$ & $0.3 \%$ \\
\hline & RA3 & $63.8 \%$ & $23.4 \%$ & $7.9 \%$ & $3.2 \%$ & $1.7 \%$ \\
\hline & RA4 & $73.2 \%$ & $21.6 \%$ & $3.9 \%$ & $0.9 \%$ & $0.3 \%$ \\
\hline & RA5 & $83.6 \%$ & $13.3 \%$ & $2.3 \%$ & $0.6 \%$ & $0.2 \%$ \\
\hline \multirow{2}{*}{ 气ั 옹 } & ZO1 & $59.8 \%$ & $28.6 \%$ & $7.9 \%$ & $2.5 \%$ & $1.1 \%$ \\
\hline & ZO2 & $80.9 \%$ & $16.1 \%$ & $2.3 \%$ & $0.5 \%$ & $0.2 \%$ \\
\hline
\end{tabular}

Table 16 - Distribution of income level, disability and main work type

\begin{tabular}{|c|c|c|c|c|c|c|}
\hline & \multicolumn{5}{|c|}{ Income level (NR) } \\
\hline & & NR1 & NR2 & NR3 & NR4 & NR5 \\
\hline \multirow{2}{*}{ 己ิ } & PCD & $64.2 \%$ & $26.0 \%$ & $6.7 \%$ & $2.1 \%$ & $0.9 \%$ \\
\hline & Npcd & $65.9 \%$ & $25.1 \%$ & $6.3 \%$ & $1.8 \%$ & $0.8 \%$ \\
\hline \multirow{7}{*}{ 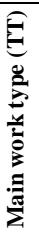 } & TT1 & $22.6 \%$ & $60.6 \%$ & $12.3 \%$ & $3.3 \%$ & $1.2 \%$ \\
\hline & TT2 & $16.6 \%$ & $42.3 \%$ & $26.8 \%$ & $9.8 \%$ & $4.5 \%$ \\
\hline & TT3 & $63.6 \%$ & 30.8 & $4.4 \%$ & $1.0 \%$ & $0.3 \%$ \\
\hline & TT4 & $41.6 \%$ & $39.1 \%$ & $13.0 \%$ & $4.3 \%$ & $2.0 \%$ \\
\hline & TT5 & $6.4 \%$ & $24.8 \%$ & $31.3 \%$ & $21.2 \%$ & $16.3 \%$ \\
\hline & TT6 & $94.7 \%$ & $3.9 \%$ & $1.0 \%$ & $0.2 \%$ & $0.1 \%$ \\
\hline & TT7 & $94.0 \%$ & $5.1 \%$ & $0.7 \%$ & $0.2 \%$ & $0.1 \%$ \\
\hline
\end{tabular}

Looking at Figure 13, there are greater proportions of people who do not have disabilities in: military and statutory civil servants, employees with a formal contract, selfemployed and employers, while disabled people have greater proportions for the following types of work: employees without a formal contract, workers in production for their own consumption and unpaid workers. Analysing this scenario, it is possible to verify that disabled people end up mostly with the worst working conditions. 
Still in Figure 13, there is also a greater predominance by work type by age group: selfemployed workers predominate in the age group between 55 and 83 years; workers for their own consumption: under 13 years; without a formal contract age between 13 and 18 years; with a formal contract between 18 and 55 years, and, between 90 and 92 years; selfemployed between 55 and 83 years; in consumption itself between 83 and 90 years, and finally; relay between own account and workers in production for their own consumption from 92 years old or more.

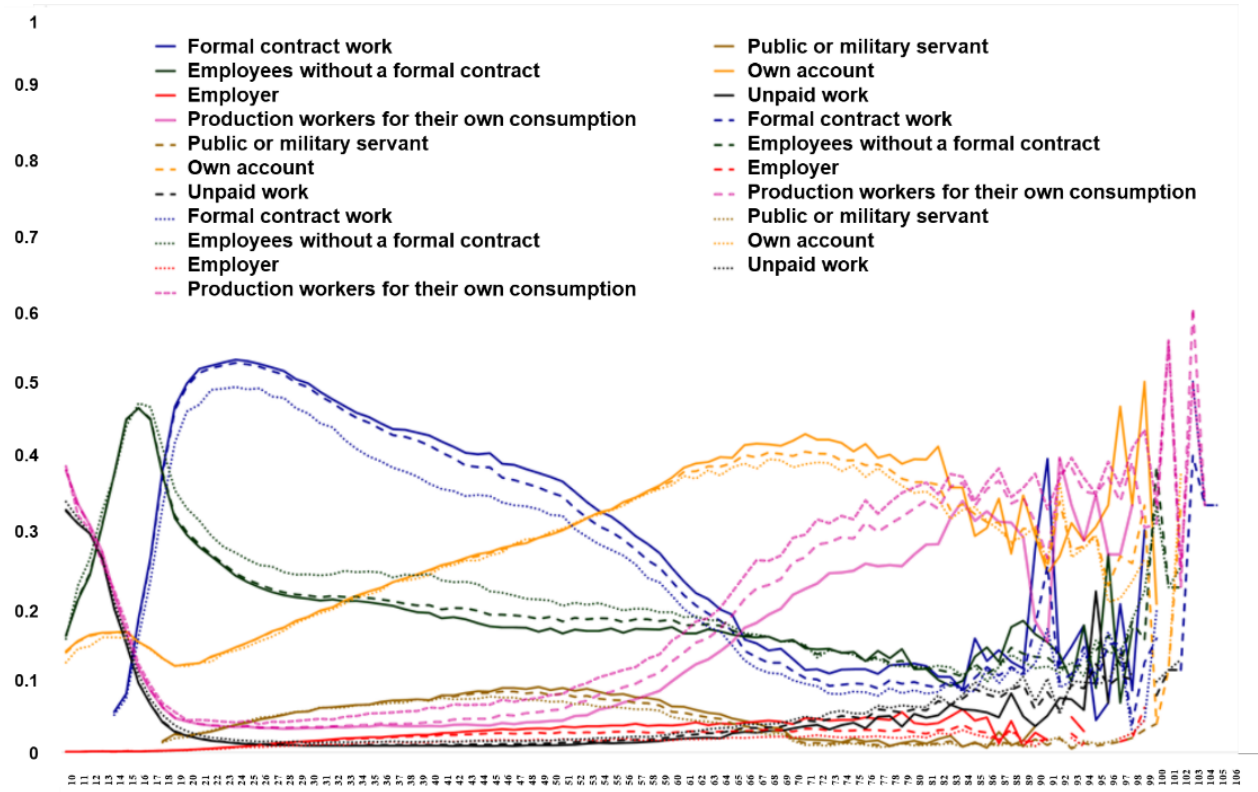

Figure 13 - Profile graph for Main work type.

Figure 14 presents the profile graph for the income variable, with each category representing a profile, being: between 0 and 1 minimum wage (in black), between 1 and 3 minimum wages (in brown), between 3 and 7 minimum wages (in red), between 7 to 15 minimum wages (in green), and finally, from 15 minimum wages (in blue).

Examining Figure 14, we conclude that disabled people are predominant in the salary range between 0 and 1 minimum wage and without disabled people are the majority in all others.

In Figure 14, it is also noted that income between 0 and 1 minimum wage represent 64.7\%; between 1 and 3 minimum wages represent 25.8\%; between 3 and 7 minimum wages $6.6 \%$; between 7 and 15 minimum wages $1.7 \%$, and, finally, higher than 15 minimum wages represent $0.9 \%$.

For the group formed by without disabled people $64.2 \%$ have an income between 0 and 1 minimum wage; $26.0 \%$ with income between 1 and 3 minimum wages; $6.7 \%$ with an income between 3 and 7 minimum wages; $2.1 \%$ with an income between 7 and 15 minimum wages, and finally; $0.9 \%$ with income above 15 minimum wages. 
Finally, for the disabled people, $65.9 \%$ have an income between 0 and 1 minimum wage; $25.1 \%$, income between 1 and 3 minimum wages; $6.3 \%$, between 3 and 7 minimum wages; $1.8 \%$, income between 7 and 15 minimum wages; and finally; $0.8 \%$ have an income above 15 minimum wages.

Analysing these data, it is possible to verify a great social inequality in the population, because, while more than $60 \%$ have an income below the minimum wage, less than $1 \%$ has an income above fifteen minimum wages.

Finally, it can also be seen that $64.2 \%$ of without disabled people and $65.9 \%$ of disabled people have income below the minimum wage, while $0.9 \%$ of without disabled people and $0.8 \%$ of disabled people have an income above 15 minimum wages. This means that, in addition to inequality in the population, it generates inequality between people with and without disabilities.

Finally, the profile graph for instruction level is shown, and for instruction level between uneducated and incomplete elementary school (NI1 - brown), between complete elementary school and incomplete middle school (NI2 - red), between complete middle school and incomplete higher education (NI3 - blue) and complete higher education or more (NI4 - green).

Studying the graph in Figure 15, it is noted that the group formed by people between uneducated and incomplete elementary school has, in proportional terms, dominated by disabled people while the other levels from the complete fundamental level or more predominate without disabled people.

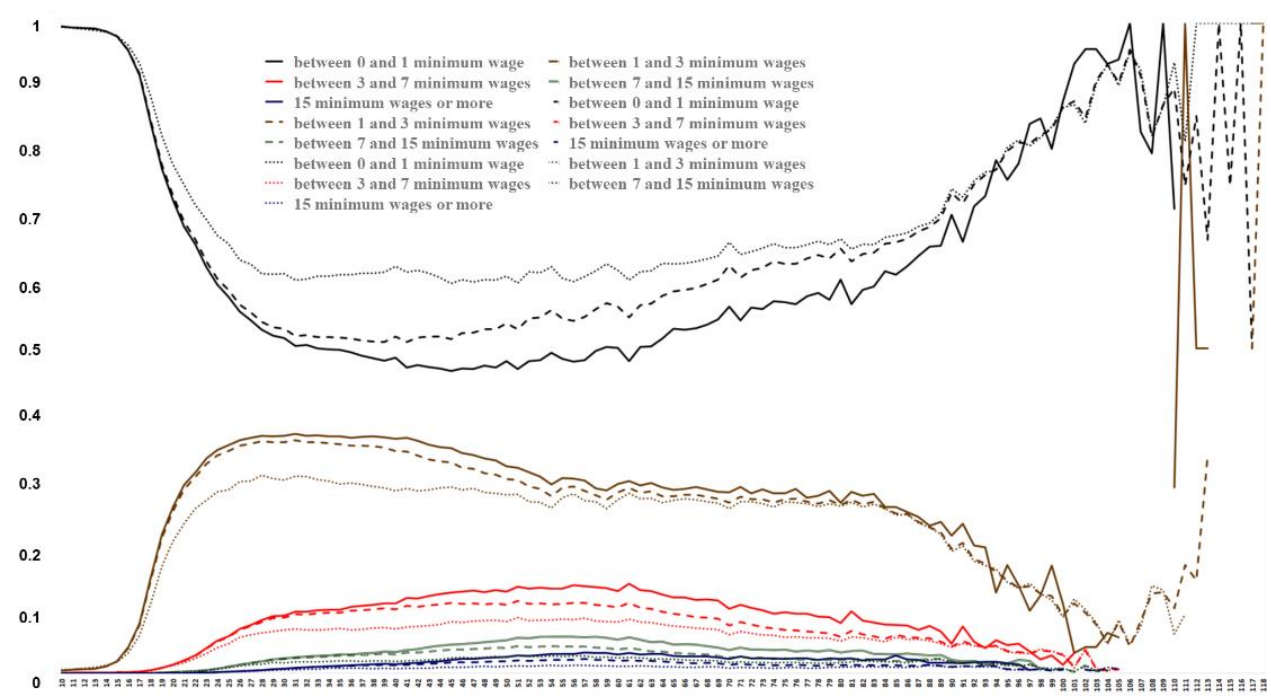

Figure 14 - Profile graph for income level.

In Figure 15, there is also a greater predominance of instruction level by age group: between the ages of 0 to 14 years and over 27 years, a higher prevalence for instruction level between uneducated and incomplete elementary school; between the ages of 14 to 17 years, a greater predominance for education level between complete elementary and incomplete high school; between the ages of 17 to 27 years there is a predominance of the 
education level between complete high school and incomplete higher education; from the age of 27 (around 1980 or later) there is a strong predominance, in terms proportional to the order: uneducated and incomplete elementary school; followed by complete elementary and incomplete high school; complete high school and incomplete college, and finally; complete higher education or more, and finally; for a complete higher education level or more, there is a year-on-year growth between the ages of 16 to 58 years old, and after that it decreases again.

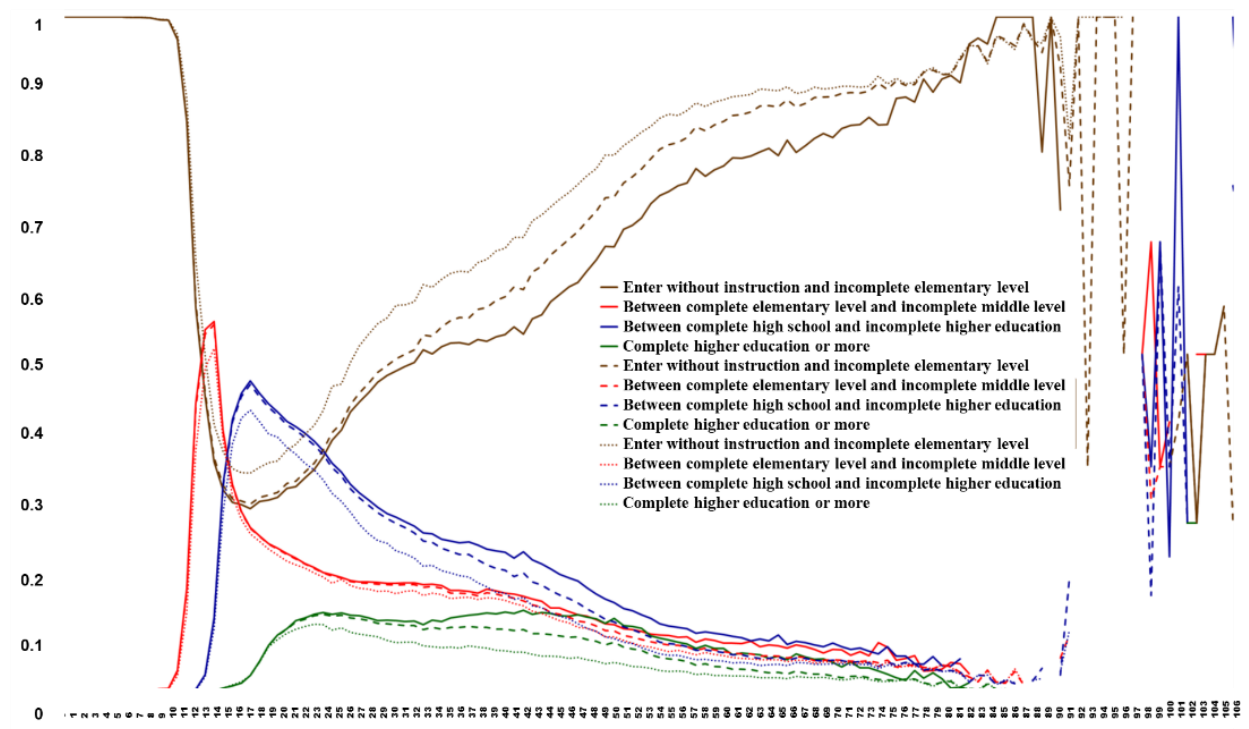

Figure 15 - Profile graph for instruction level.

The reason that justifies the predominance of education level between uneducated and incomplete elementary school aged over 27 years is the fact that primary and secondary education was more difficult for a large portion of the population, making with a large part of this population being forced to stop studying, mainly in more distant places, and this situation is more impractical and difficult for disabled people, whose accessibility conditions were much lower, as reflected in the graph, in which there is a greater distance between disabled people (brown dotted) and without disabilities (continuous brown streak).

\section{Conclusions}

I - HDI distribution

Municipalities with higher human development indices are more concentrated in the south and southeast regions, while municipalities with lower human development indices are more concentrated in the north and northeast regions. 
II - Income distribution and profile graph

i) For the variable number of goods, it was found that higher income for people without disabilities in all situations; more frequent presence of people in possession of four assets, and finally; disabled people greater proportions of possession of 0 to 5 assets, while without disabilities people have greater proportions of possession between 6 to 10 assets;

ii) For the race variable, it was observed that the most numerous race is white, however, the races contemplated by the quota law formed by blacks, browns and indigenous represent the majority in the population; less numerous breeds are indigenous and yellow, finely; when comparing people with and without disabilities in a comparative way, disabled people have higher proportions of blacks and yellows, while people without disabilities have higher proportions of white, brown and indigenous;

iii) Next, considering the variable expanded instruction level was found: most frequent instruction level was incomplete fundamental level up to a maximum of the fourth grade and the least frequent was a complete doctorate level or more; people without disabilities have higher income for instruction level of at most incomplete higher instruction, while, disabled people have higher income for complete higher instruction or more, and finally; in proportional terms, disabled people have higher proportions for those without education and instruction level from the fourth grade onwards, while people without disabilities have higher proportions of incomplete between literate and up to the fourth grade and complete elementary level or more;

iv) Finally, for main work type, it was concluded that disabled people have higher income for employing functions, unpaid work and production for their own consumption, while people without disabilities, achieve higher income in work functions with a formal contract, income and informal work; people with and without disabilities have higher income for employers; for disabled people, the worst income is for unpaid work and for people without disabilities, the worst income is for unpaid work, and finally; proportionally, disabled people present higher proportions of work without a formal contract, civil servant or military, self-employed, informal work, unpaid work and in production for their own consumption, while people without disabilities present greater proportions of formal work. and employers, and finally;

v) Among people with at least one disability, $77.9 \%$ have visual impairments and $28 \%$ have multiple disabilities.

II - Crossings between variables

People with low vision disability have greater difficulty in achieving a better instruction level, better working conditions, higher income, more children and a worse life quality, better remuneration than total visual disabled.

III - On fertility index, the main conclusions obtained were:

The variables levels that obtained the highest fertility rates were: visual; hearing; physics; visual and hearing; visual and physical; hearing and physical; visual, hearing and physical; visual, hearing and intellectual; physical and intellectual visual; auditory, physical and intellectual, and finally; visual, auditory, physical and intellectual for simple disability type.

Extended instruction level between uneducated and incomplete fundamental level for extended education level; blacks, browns and indigenous for race; rural to zone; production work for own consumption in work type; disabled person for disability, and finally; income level between 1 to 3 minimum wages for income 
It is noted that the majority of these groups that obtained higher fertility indexes are considered more vulnerable. In this case, the greater the number of children, the greater their impoverishment tends to be, with greater difficulties in terms of employability, more precarious infrastructures for housing, health and education, as is the case, for example, in rural areas and in indigenous villages.

These fertility rates are highly correlated with the levels of income distribution in these groups considered.

The need to invest in more productive technologies, guarantee the inclusion of individuals in society by increasing job opportunities, the periphery of urban canters, disabled people and the reduction of social inequalities.

IV - Distribution of income level by disability type, expanded instruction level, race, urban or rural area, disability and main work type.

The levels considered most vulnerable show a worse income distribution (higher proportion of people with an income between 0 and 1 minimum wage and lower proportion of people with an income above 15 minimum wages) which ends up confirming the same levels that have high fertility rates.

$\mathrm{V}$ - Regarding the profile graphics for the type of main job, income level and education level.

Disabled people are inferior when compared to without disabled people in terms of education (more concentrated in education between uneducated and incomplete elementary), work (more concentrated in work for their own consumption and without remuneration), income level (more concentrated in income between zero and one minimum wage).Which reflects in disabled people the worst living conditions due to the accessibility lack and inclusion.

To continue this research, it suggests other studies considering other variables and repetition of data collection from time to time, which could be, for example, every two years so that you can also consider in these studies the disabled people evolution over time and propose as a technique of model analysis of longitudinal data.

Public policies implementation aimed at the disabled people segment involving studies in the different areas of the federal, state and municipal governments in the most diverse areas of technological and scientific knowledge.

\section{Acknowledgements}

First of all, I thank Professor Júlia Maria Pavan Soler for the encouragement and indication of the theme and second to IBGE for the availability of data from the 2010 Demographic Census. Also, I would like to thank the editor for his comments.

OLIVEIRA, P. T. M. S. Desigualdade e deficiência: em termos estatísticos, o que mais precisamos saber? Rev. Bras. Biom. Lavras, v.39, n.3, p.460-491, 2021. 
- RESUMO: Desigualdade social é o fenômeno que ocorre a diferenciação entre pessoas no contexto de uma mesma sociedade, colocando alguns indivíduos em condições estruturalmente mais vantajosas do que outros. Ela manifesta-se em todos os aspectos: social, política e econômico. As principais causas da desigualdade são falta de investimento nas áreas sociais, saúde e educação e corrupção. Entre as consequências da desigualdade destacamos: aumento da violência, pobreza e atraso no progresso econômico e aumento do desemprego. Entre os principais tipos de desigualdade destacamos entre: pessoas com e sem deficiência, regióes, raças; renda e sexo. Para mensurar essa desigualdade destacamos IDH, Theil e MPI. Pessoa com deficiência é toda pessoa que apresenta perda ou anormalidade que gere incapacidade para o desempenho de uma ou mais atividades e estas características dificultam sua inclusão social, acesso no mercado de trabalho, transporte, educação, financiamento e treinamento; barreiras urbanas e ambientais, e, finalmente; desconhecimento dos empregadores. Situações como essas proporcionam a pessoas com deficiência menores salários quando empregadas, pior poder aquisitivo, menor participação social proporcionando maior exclusão e situações em desvantagens ao serem comparadas a sem deficiência. Para este trabalho utilizamos técnicas exploratória de análise considerando conjuntos de dados do Censo do IBGE 2010 e do PNUD.

- PALAVRAS-CHAVE: Análise exploratória de dados; censo demográfico 2010; índice de desigualdade social; pessoa com deficiência; estudos por município; análise de perfis.

\section{References}

ANDRADE, D. F.; SINGER, J. M. Análise de Dados Longitudinais. Campinas: Associação Brasileira de Estatística,1986.

AITCHISON, J. The Statistical Analysis of Compositional Data. Chapman Hall, The Blackburn Press, 2011.430p.

BASTOS, J. L.; DUQUIA, R. P. One of the most used epidemiological. Scientia Medica, 2007, v.23, n.2, p.229-232.

BAXTER, M. J. Detecting multivariate outliers' artefact compositional data, Archaeometry, v.41, n.2, p.321-338, 1999.

BUCCIANTI, A.; MATEU-FIGUERAS, G.; PAWLOWSKY-GLAHN, V. Compositional Data Analysis in the Geosciences from Theory to Practice. 2006. Geological Society Special 264.

CAETANO, A. J. Fecundidade abaixo da reposição, população estacionária por migração e efeitos sobre a estimativa etária. Revista Brasileira de Estatística Populacional, v.25, n.2, p.325-334, 2008.

CARVALHO, J. O. F. Soluções tecnológicas para viabilizar o acesso do deficiente visual à Educação à Distancia no Ensino Superior. 2001. Faculdade de Engenharia Elétrica e Computação, UNICAMP, campinas-SP, 2001.221p.

CHAYES, F. On correlations between variables of constant sum. Journal of Geophysical Research, v.65, n.12, p.4185-4193, 1960.

CONCEIÇÃO, P. Human Development Report 2019. New York: UNDP, 2019. 366p.

DIAS, L. P. F. Inclusão social de cidadãos portadores de deficiência(s) residentes no Concelho de Miranda do Douro. 2011. 110f. Relatório de Estágio (Mestrado em Educação Social) - Escola Superior de Educação de Bragança, Bragança, Portugal, 2011. 
DOMINGOS, M. A. Sentidos e significados produzidos por alunos e professores no cotidiano numa escola do sistema regular de ensino a partir da inclusão de alunos portadores de necessidades educacionais especiais. 2006.373f. Dissertação (Mestrado em Educação) - Faculdade de Educação, PUC-MG, Belo Horizonte, 2006.

FERRO, F. F. Instrumentos para medir a qualidade de vida no trabalho e a ESF: uma revisão da literatura. 2012. 92f. Dissertação (Especialização em atenção básica em saúde da família), Universidade Federal de Minas Gerais, Brumadinho, 2012.

FIGUEIRA, E. Caminhando em silêncio. São Paulo: Giz Editorial e Livraria Ltda., 2008.

GARCIA, V.G. Pessoas com deficiência e o mercado de trabalho. 2010. Tese (Doutorado em Economia) - Instituto de Economia, UNICAMP, Campinas, 2010.

GIOLO, S. R. Uma introdução à análise de dados categóricos com aplicações. São Paulo: Edgar Blucher, 2017.

HAWKING, S. W. World report on disability. Geneva: World Health Organization, 2011.3 $31 \mathrm{p}$.

OLIVEIRA, P. T. M. S. Análise de perfis e de confundimento para qualidade de vida: pessoas com deficiência e raça. In: 62 RBRAS e 17 SEAGRO, 1, 2017, Lavras. Resumo... Editora UFLA, 2017. P.1-36.

SILVA, O. M. A epopeia ignorada. São Paulo: CEDAS, 1986.

Received on 09.07.2020

Approved after revised on 03.05.2021

Rev. Bras. Biom., Lavras, v.39, n.3, p.460-491, 2021 - doi: 10.28951/rbb.v39i3.528 